\title{
Peer-to-Peer Confirmation, Positive Automatic Thoughts, and Flourishing of Computer Programming E-Learners
}

\author{
Aiste Dirzyte ${ }^{1,2, *(\mathbb{D})}$, Živilè Sederevičiūtè-Pačiauskienè ${ }^{1}$, Jolita Šliogerienè ${ }^{1}$ (D) Aivaras Vijaikis ${ }^{2}$, \\ Aidas Perminas ${ }^{3}$, Lukas Kaminskis ${ }^{4}$, Giedrius Žebrauskas ${ }^{4}$ and Kęstutis Mačiulaitis ${ }^{4}$ \\ 1 Faculty of Creative Industries, Vilnius Gediminas Technical University, Sauletekio Ave. 11, \\ 10221 Vilnius, Lithuania; zivile.sedereviciute-paciauskiene@vilniustech.lt (Ž.S.-P.); \\ jolita.sliogeriene@vilniustech.lt (J.Š.) \\ 2 Institute of Psychology, Mykolas Romeris University, Ateities 20, 08303 Vilnius, Lithuania; \\ aivaras.vijaikis@gmail.com \\ 3 Department of Psychology, Vytautas Magnus University, K. Donelaičio Str. 58, 44248 Kaunas, Lithuania; \\ aidas.perminas@vdu.lt \\ 4 Turing College, Žalgirio g. 90-D, 09300 Vilnius, Lithuania; lukas@turingcollege.com (L.K.); \\ giedrius.zebrauskas@turingcollege.com (G.Ž.); kmaciulaitis@tschool.io (K.M.) \\ * Correspondence: aiste.dirzyte@vilniustech.lt
}

Citation: Dirzyte, A.; Sederevičiūtè-Pačiauskienè, Ž; Šliogerienè, J.; Vijaikis, A.; Perminas, A.; Kaminskis, L.; Žebrauskas, G.; Mačiulaitis, K. Peer-to-Peer Confirmation, Positive Automatic Thoughts, and Flourishing of Computer Programming E-Learners. Sustainability 2021, 13, 11832. https://doi.org/10.3390/su132111832

Academic Editor: JESÚSNICASIO GARCÍA-SÁNCHEZ

Received: 21 September 2021 Accepted: 23 October 2021 Published: 26 October 2021

Publisher's Note: MDPI stays neutral with regard to jurisdictional claims in published maps and institutional affiliations.

Copyright: (c) 2021 by the authors. Licensee MDPI, Basel, Switzerland. This article is an open access article distributed under the terms and conditions of the Creative Commons Attribution (CC BY) license (https:// creativecommons.org/licenses/by/ $4.0 /)$.
Abstract: Computer programming e-learners faced stressful life circumstances and educational changes that affected the world during the COVID-19 pandemic. As the cognitive model of flourishing focuses on cognitions rather than situations themselves, it was deemed significant to identify peer-to-peer confirmation, positive automatic thoughts, flourishing, and the links between these study variables in a group of computer programming e-learners and compare the results with other e-learners. This study applied the Flourishing Scale (FS), the Automatic Thoughts Questionnaire-Positive (ATQP), and the Student-to-Student Confirmation Scale. The sample consisted of 453 e-learners, including 211 computer programming e-learners. The results revealed that computer programming e-learners differed from other e-learners in flourishing, positive daily functioning, and peer-to-peer confirmation. In both samples, positive daily functioning and positive future expectations predicted self-reported flourishing. Positive automatic thoughts and flourishing predicted peer-to-peer confirmation just in the group of computer programming e-learners. The SEM analysis revealed that peer-to-peer confirmation and positive automatic thoughts explained $57.4 \%$ of the variance of flourishing in the computer programming e-learners group and $9.3 \%$ of the variance in the social sciences e-learners group, $\chi^{2}=81.320, \mathrm{df}=36, p<0.001$; $\mathrm{NFI}=0.963$; TLI $=0.967$; $\mathrm{CFI}=0.979 ; \mathrm{RMSEA}=0.075$ [0.053-0.096]; SRMR $=0.033$. The findings signify the importance of peer-to-peer confirmation and positive thoughts for computer programming e-learners' psychological well-being. Nevertheless, the results of this particular study should be regarded with caution due to the relatively small sample size and other limitations. In the future, it would be valuable to identify the underlying mechanisms and the added value of positive states such as flow, which have recently received the increased attention of researchers.

Keywords: peer-to-peer confirmation; positive automatic thoughts; flourishing; computer programming; e-learning

\section{Introduction}

Computer programming education faced difficulties that affected the world during the COVID-19 pandemic [1]. The preliminary research on the costs of the coronavirus outbreak on mental health reveals a statistically significant increase in the rates of unsatisfactory psychological well-being [2], anxiety [3], stress [4-6], and burnout [7].

Furthermore, many countries worldwide face the need for rapid implementation of e-learning. As Bond et al. [8] point out, "the COVID-19 pandemic led to the unprecedented 
situation of having to switch to online instruction, with considerable impact on students in all levels of education" [8].

Research indicates that in the times of the COVID-19 quarantine some university students develop emotional difficulties due to stressful life circumstances [9], which may affect satisfaction with e-learning [10] or might lead to diminished e-learning motivation or even absence of it [11].

Even though some studies demonstrated the negative impact of changed conditions, the cognitive model of emotional difficulties refers not to life circumstances itself [12], but cognitive processes or, at least, interactions between situations and cognitions [13-15]. Biased information processing and cognitive specificity of misleading beliefs play a central role in triggering emotional difficulties [16]. On the other hand, positive automatic thoughts promote psychological well-being [17] and result in the absence of depression [18]. These effects are very important for education, as depression increases the rates of dropout and lowers educational attainments [19-22], while flourishing is linked to many positive educational outcomes $[23,24]$.

This study explores the role of cognitive specificity of beliefs and psychological flourishing in e-learning based education. As the student-centered approach delineates the importance of peer-to-peer confirmation in education, this study also aimed to identify associations between positive thoughts, flourishing, and peer-to-peer confirmation.

\subsection{Student-Centered Approach and Peer-to-Peer Confirmation}

A student-centred approach as a keystone of education has been researched for several decades [25-27], revealing new roles of educators and learners. The student-centred approach has brought more emphasis on learners' activity and their responsibility for the learning outcomes, while the teacher's role switched to facilitating and fostering students' discovery, collaboration, cooperation, and engagement in constructing new knowledge [27].

Having moved to e-learning, a great shift in education in terms of a student-centred approach has been witnessed as the new roles had to be reconsidered [28]. Constructs, such as student support [28,29], peer-to-peer relationship, connectedness, or instructional dissent [30-33] have been widely explored. These investigations led to new areas of research to what extent students influence each other in educational settings. Johnson and LaBelle [34,35] defines such student-centric construct in the instructional environment as "student-to-student confirmation" [34,35].

The concept of "confirmation" in the academic environment has been analysed from two perspectives: teachers' confirming messages and students' communicative behaviours [36]. "Confirmation" stipulates a wish not only to interact with another individual but also to engage in a relationship with another person [37]. Recently, confirmation has been widely researched in educational settings [34,38], emphasizing the impact of confirmation by both teachers and peers revealing positive perceptions and learning outcomes for students $[35,38]$.

The impact of teacher confirmation has been analysed through four dimensions: responding to students, demonstrating interest in student learning, teaching style, and the absence of disconfirmation [38]. Research revealed that teacher confirmation directly influences students' communicative behaviours [39].

A study conducted by Goodboy and Myers [39] showed that teacher confirmation has a constructive impact on students' active participation, cognitive and affective learning, motivation, and satisfaction [39]. Other studies revealed that students, who receive confirming messages from peers, report greater affective learning, motivation, and engagement [34,35].

A study conducted by Sidelinger and Booth-Butterfield [32] revealed that "peer-topeer connectedness mediated the relationships between teacher confirmation behaviours and in-class student involvement", which also proved that peer-to-peer connectedness is an important predictor of student involvement and a classroom resource [32].

Peer-to-peer confirmation is "the transactional process by which students communicate that they endorse, recognize, and acknowledge their peers as valuable and significant 
individuals" [34,35]. Johnson and LaBelle's [34] research reveals that students declare their peers of great value and significance in terms of three dimensions of peer-to-peer confirmation: acknowledgement, assistance, and individual attention. Acknowledgement is viewed as peers' confirmation of performance level, knowledge or developed and demonstrated skills in a course. Peer-to-peer confirmation via assistance is described as an act of giving or receiving help in the educational setting [34,35]. Individual attention is considered peers' support, encouragement or expressed interest in another individual's well-being [34].

Peer-to-peer confirmation has been analyzed in relation to their engagement in the course, which happens both inside and outside the classroom [40,41]. The research results disclosed the connection between student confirmation and out of class behaviours, such as discussing course content and studying with peers. All three dimensions of peer-to-peer confirmation (acknowledgement, assistance, and individual attention) demonstrated a significant positive relationship with the oral in-class behaviours, thinking about course content, and out of class behaviours of student engagement, but were not related to silent in class behaviours [41].

In summary, previous research suggested several positive factors related to peer-topeer confirmation, but these results were based on face-to-face teaching and learning, inside and outside classroom interactions. An exploration of peer-to-peer confirmation in a distant learning environment might provide supplemental information on the contributing factors.

\subsection{Psychological Flourishing}

Psychological flourishing is a concept that encompasses some of the well-being (subjective, psychological, social, emotional) components [42,43], is synonymous with a high level of psychological well-being [42], and is linked to mental health [44-46]. Flourishing is characterized as individuals' evaluations of how well they feel they are functioning in their lives [44]. Literature suggests several theoretical conceptualizations of flourishing:

According to Diener et al. [42], flourishing incorporates purpose and meaning in life, positive relationships, engagement, competence, self-acceptance and self-esteem, optimism, and social contribution towards the well-being of others [42].

Hupert and So [47] identify ten features of positive well-being: positive feeling and positive functioning, i.e., hedonic, and eudemonic aspects of well-being: competence, emotional stability, engagement, meaning, optimism, positive emotion, positive relationships, resilience, self-esteem, and vitality [47].

Keyes' [48] theoretical model of flourishing consists of positive relationship, positive affect (interest), purpose in life, positive affect (happiness), social contribution, social integration, social growth, social acceptance, social coherence, environmental mastery, personal growth, autonomy, life satisfaction [48].

Seligman [49] describes flourishing by positive relationships, engagement, meaning and purpose, accomplishments/competence, and positive emotions [49].

Despite the lack of consensus on a theory, conceptualization, and definition of flourishing, there is substantial agreement in all operational definitions that flourishing is a combination of a set of hedonic and eudemonic indicators, with an overlap in the areas of (1) positive relationships, (2) positive affect and engagement, and (3) meaning and purpose [50,51]. "Positive relationships" delineates a person's perception to what extent he receives help and support from others when he needs it and to what extent the person has been feeling loved, or how much he is satisfied with personal relationships. "Engagement" outlines how much a person becomes absorbed in personal activities, to what extent he feels excited and interested in things. "Meaning and purpose" defines the extent a person perceives leading a purposeful and meaningful life, to what extent he recognizes personal activities as valuable and worthwhile, and has a sense of direction in his life [51].

Predictors of flourishing include academic achievement [23,24], supportive college environments, ease with transitioning, sense of belonging [52], volunteering, and servicelearning [53]. On the other hand, students who have higher perceptions of 'social-psychological prosperity' that is characterized by greater competence, purpose in life, self-esteem, op- 
timism, and harmonious relationships, report that they invest greater efforts in completing academic tasks and experience positive emotions when doing academic activities [54]. Furthermore, flourishing is positively linked to greater behavioural and emotional engagement in an educational context. Several studies reported similar results: well-being increases academic engagement [55], motivation [56], and it matters for successful learning [23,24].

Next, flourishing is related to various desired outcomes such as life satisfaction, physical and mental health [57], self-enhancement [58], positive emotions, and persistence in pursuing achievement goals orientation [54]. These parameters are essential for students' academic achievement, study involvement, dropout prevention, and successful careers. Goal orientation and self-enhancement lead to better academic achievement, and improved achievement lead to better academic self-concept and academic motivation [59].

In contrast to flourishing, life dissatisfaction is linked to low levels of health, higher levels of depression, personality problems, and health inappropriate behaviour [60], which negatively influences academic achievements and engagement. Research indicates that students struggling with mental illnesses are at greater risk of academic failure [61].

Furthermore, positively minded students are more active, tend to appreciate and support more often and more positively their peers, and vice versa, those who receive more and positive support achieve better results [55,62-65]. Therefore, parameters preconditioned by flourishing are essential to successful learning and are called 'the central purpose of education" [66] (p. 42).

\subsection{Positive Automatic Thoughts}

Automatic thoughts are the "stream of thoughts, ideas and images which constantly accompany an individual as he or she proceeds through daily life" [67] (p. 70). The importance of thought automaticity has been emphasized in modern cognitive theories. There is a distinction between fast, unconscious, automatic, and effortless thinking and slow, conscious, deliberate, and effortful thinking [68]. Conceptualizing specific thoughts as "automatic" means that these thoughts happen spontaneously, without determined intent or effort.

Wong [69] found that negative automatic thoughts were inversely correlated with life satisfaction and happiness and concluded that a higher ratio of positive automatic thoughts to the sum of positive and negative automatic thoughts led to better mental health outcomes [69]. A person's negative automatic thoughts about the self and the world, supported by their intermediate and core beliefs, set up a self-reinforcing cycle that predisposes an individual to emotional deregulation and maladaptive behaviour [16].

Research also proposed, however, that positive automatic thoughts play a role in overall psychological functioning. For instance, Ingram and Wisnicki [17] identified cognitive dimensions associated with good moods and positive experiences: positive daily functioning, positive self-evaluation, others' evaluations of the self, and positive future expectations. Empirical evidence supports that positive automatic thoughts are linked to psychological health and the absence of depression. Of course, the absence of depression does not necessarily correspond to exceptional psychological well-being. Studies focusing only on negative mood states may not shed light on the nature and correlates of positive functioning [18]. However, many studies confirm that depression substantially reduces physical, social, and cognitive functioning, is a cause of dropouts, and lowers educational attainments [19-22]. All these aspects are fundamental in autonomous e-learning as the learners have to deal with the challenges independently. The decision to finish an e-learning course requires motivation, everyday efforts, high self-esteem $[23,24,55,56]$.

Research suggests that e-learning meets many challenges; therefore, an analysis of contributing factors might provide additional information on successful learning [70-73]. Moreover, there is a lack of empirical data on the links between automatic thoughts, peerto-peer confirmation, and flourishing, especially, in the context of e-learning. Consequently, the purpose of this study was to explore the links between positive automatic thoughts, flourishing, and peer-to-peer confirmation in e-learning based education. 
This study targeted students enrolled in e-learning-based computer programming education because computer programing is one of the most challenging learning tasks [74], demonstrating the highest rates of learning failures [75]. Moreover, learners worldwide are encouraged to attain computer programming skills [76], though acquiring computer programming skills might be extremely challenging for some learners [77].

In this survey, we have chosen to analyze two samples: those who participate in e-learning-based computer learning courses and those who study social sciences in various university programs, but they are studying remotely due to the COVID-19 pandemic.

Even though studies are suggesting that computer programming learners differ from other learners in their personality traits, namely, lower extraversion [78], which implies possible differences in peer-to-peer confirmation skills, but research indicates no significant dissimilarities in psychological flourishing or positive thinking of learners. Thus, it is unclear whether computer programming learners are better at peer-to-peer confirmation, and whether the associations between positive automatic thoughts, flourishing, and peerto-peer confirmation differ between participants and non-participants of e-learning based computer programming courses.

In summary, computer programming e-learners faced stressful life conditions that affected the world during the COVID-19 pandemic. As the cognitive model of flourishing suggests that cognitions rather than conditions determine psychological wellbeing and perceptual outcomes, it was considered significant to explore the links between positive automatic thoughts, flourishing, and peer-to-peer confirmation, and compare these links in groups of computer programming and other e-learners. This study is the first which investigates the links between positive automatic thoughts, self-reported psychological flourishing, and peer-to-peer confirmation in e-learning-based education, including computer programming learning. Most of the previous studies targeted the links between peer-to-peer confirmation and mental health $[30,34,35,79]$, learning motivation and mental health indicators, such as depression and anxiety $[1,34,35]$, with a narrow focus on psychological wellbeing [79]. This study primarily targeted the positive psychology construct of flourishing and positive automatic thoughts in relation to peer-to-peer confirmation in e-learning. The context of the COVID-19 quarantine, which brought the rapid implementation of e-learning [80], facilitated the comparison of associations between the study variables in different samples.

This study attempted to answer research question whether peer-to-peer confirmation, positive automatic thoughts, flourishing and the links between them differ in groups of computer programming and other e-learners. Thus the goal of this study was to identify peer-to-peer confirmation, positive automatic thoughts, flourishing, and the links between these study variables in a group of computer programming e-learners and compare the results with other e-learners.

Based on previous research, we hypothesized that:

Hypothesis 1 (H1). Computer programming e-learners do not differ in their positive automatic thoughts and self-reported flourishing from other e-learners;

Hypothesis 2 (H2). Computer programming e-learners differ in their peer-to-peer confirmation from other e-learners;

Hypothesis 3 (H3). Positive automatic thoughts predict self-reported flourishing in both groups of participants and non-participants of e-learning based computer programming courses;

Hypothesis 4 (H4). Self-reported flourishing and positive automatic thoughts predict peer-topeer confirmation of participants and non-participants of e-learning based computer programming courses; 
Hypothesis 5 (H5). Associations between self-reported flourishing, positive automatic thoughts and peer-to-peer confirmation differ between participants and non-participants of e-learning based computer programming courses.

\section{Materials and Methods}

\subsection{Sample}

In the full sample of 453 participants, a total of 453 participants had no missing data. The study's subjects included 32.7 percent of males $(\mathrm{N}=148)$ and 67.3 percent of females $(\mathrm{N}=305)$. The respondents' mean age was 26.10 years $(S D=8.363,95 \% \mathrm{CI}=25.33,26.88$, age range $=$ from 18 to 56 years). 242 (53.4\%) of participants studied in e-learning based computer programming courses organized by Turing College. The comparative group consisted of $211(46.6 \%)$ respondents who studied social sciences at various Lithuanian universities, but were studying remotely due to the COVID-19 pandemics.

At the time of the research, both groups of e-learners (computer programming and social sciences) were undertaking their studies. E-learners were informed about the study by e-mail and provided their consent to participate in the research. Participation in the study was voluntary, and the participants did not receive any compensation. The procedure was administered online at https:/ / www.psytest.online (accessed on 8 August 2021) and followed the General Data Protection Regulation (GDPR) guidelines and the Declaration of Helsinki. The study was approved by the Institutional Review Board of the Institute of Management and Psychology.

\subsection{Instruments}

This study applied three instruments, the Lithuanian translated version of the Flourishing Scale (FS) [42], the Lithuanian translated version of the Automatic Thoughts QuestionnairePositive (ATQP) [17], the Lithuanian translated version of the Student-to-Student Confirmation Scale, [35]. To ensure that the Lithuanian items corresponded as closely as possible to the English items, the original items of both instruments were translated into Lithuanian and back-translated.

\subsubsection{The Flourishing Scale}

To assess psychological flourishing, we applied the Flourishing Scale (FS) of Ed Diener and colleagues consisting of 8 items [42]. The Flourishing Scale measures the respondent's self-perceived success in important areas such as relationships, self-esteem, purpose, and optimism. The scale provides a single psychological well-being score. In our study, the response pattern followed a 5-point Likert scale ranging from 5 (totally agree) to 1 (totally disagree). The Flourishing Scale over the last decade has been validated across several populations (e.g., post-secondary students) [58,81-83], older adults [84]. Validation studies confirmed the one-dimensional structure of the FS, evidencing the instrument's internal consistency [42].

\subsubsection{The Automatic Thoughts Questionnaire-Positive}

We applied the Automatic Thoughts Questionnaire-Positive (ATQP) [17] to assess positive automatic thoughts. The ATQP, a 30-item self-report instrument, measures positive automatic thoughts. Items consist of statements representing positive automatic thoughts; respondents rated frequency of positive automatic thoughts on a 5-point Likert scale ranging from 1 (Not at all) to 5 (All the time). Item ratings are summed to produce a total score. Previous research validated the four-dimensional structure and internal consistency of the positive automatic thoughts' questionnaire [17].

\subsubsection{The Student-to-Student Confirmation Scale}

To assess peer-to-peer confirmation, we applied the Student-to-Student Confirmation Scale, developed by LaBelle and Johnson [35]. This 25-items scale assesses student's experience receiving confirmation from peers along three dimensions: individual attention, 
acknowledgment, and assistance. The individual attention dimension includes 10 items that assess participants' reception of confirming messages which let them know that they are significant as unique individuals. The acknowledgment dimension includes 9 items that assess participants' experience receiving messages that acknowledge their abilities related to academics and course content. The assistance dimension includes six items that assess participants' reception of confirmation from peers in the form of assistance or help. Participants were asked to respond on a 5-point Likert scale ranging from (1) strongly disagree to (5) strongly agree. Validation studies confirmed the three-dimensional structure of the Student-to-Student Confirmation Scale, evidencing the instrument's internal consistency [35].

In this study, for reliability and validity analysis, Cronbach's alpha, McDonald's omega, composite reliability (CR) and average variance extracted (AVE) indexes were calculated. Microsoft Excel software was used to calculate composite variability and average variance extracted, which are indicators of convergent validity. The average variance extracted should be higher than the minimum threshold of 0.5. However, according to Fornell and Larcker, even if AVE is less than 0.5, but CR is higher than 0.6, the convergent validity of the construct is still adequate [85].

Cronbach alpha, McDonald's omega, composite reliability and average variance extracted indexes for the used instruments the Flourishing Scale (FS), the Automatic Thoughts Questionnaire-Positive (ATQP), and the Student-to-Student confirmation scale in this research are presented in Table 1.

Table 1. Cronbach alphas for the Flourishing Scale (FS), the Automatic Thoughts Questionnaire-Positive (ATQP), and the Student-to-Student confirmation scale.

\begin{tabular}{|c|c|c|c|c|}
\hline Scales and Subscales & Cronbach Alpha & McDonald's Omega & $C R$ & $A V E$ \\
\hline $\begin{array}{c}\text { Automatic Thoughts } \\
\text { Questionnaire-Positive (ATQP) }\end{array}$ & 0.966 & 0.966 & 0.966 & 0.492 \\
\hline Positive daily functioning subscale & 0.934 & 0.935 & 0.935 & 0.592 \\
\hline Positive self-evaluation subscale & 0.870 & 0.872 & 0.872 & 0.534 \\
\hline Other evaluation of self subscale & 0.809 & 0.814 & 0.810 & 0.520 \\
\hline Positive future expectation subscale & 0.917 & 0.917 & 0.917 & 0.847 \\
\hline Flourishing Scale (FS) & 0.859 & 0.860 & 0.860 & 0.438 \\
\hline Student-to-Student Confirmation Scale & 0.967 & 0.968 & 0.979 & 0.696 \\
\hline Individual attention subscale & 0.957 & 0.958 & 0.958 & 0.698 \\
\hline Acknowledgement subscale & 0.949 & 0.950 & 0.949 & 0.676 \\
\hline Assistance subscale & 0.940 & 0.940 & 0.939 & 0.722 \\
\hline
\end{tabular}

$C R$, composite reliability; $A V E$, average variance extracted.

\subsection{Statistical Analysis}

For data analysis, we used SPSS v.26.0 (IBM Corp., Armonk, NY, USA). The structural equation modeling (SEM) was conducted using AMOS v.26.0 (IBM Corp., Armonk, NY, USA) and JASP v. 0.14.1.0 (University of Amsterdam, Amsterdam, The Netherlands).

Applying the SEM methodology is beneficial as it tests whether the theoretical structural relationships between the constructs are meaningful and significant [86-98]. Research suggests that several SEM methodologies can be applied for the data analysis: partial least squares structural equation modeling (PLS-SEM), and covariance-based structural equation modeling (CB-SEM). PLS-SEM is not based on covariances and thus does not have a fit measure, and CB-SEM is based on covariances and requires fit, and is assessed on the basis of reliability, convergent validity, and discriminant validity, as well as on how well the relationships between the indicator variables can be reproduced [92,94]. PLS-SEM methodology is best for applying when the research objective is exploratory, 
focused on prediction or explaining the relationships between exogenous and endogenous constructs, when the sample size is small $(n<100)$, the measurement models are complex (6 and more constructs and more than 50 indicators), the scaling of responses is ordinal or nominal, the data is secondary/archival, particularly single-item measures. In PLS-SEM, the research objective is to use latent variable scores in subsequent analyses, the structural model is estimated with a higher-order construct that has only two first-order constructs, the analysis involves a continuous moderator, the investigation examines the model for unobserved heterogeneity, and the data are not normally distributed [88,92,94]. Even though this study and the data met some of the rules of thumb for choosing the PLS-SEM (lacks solid theoretical foundation, the data were not normally distributed, etc.) and we measured several second-order constructs (peer-to-peer confirmation, positive automatic thoughts), but the data also met some of the main rules of thumb for choosing the CB-SEM. Thus we have applied the CB-SEM methodology, which is usually preferred when the research objective is confirmation of well-developed structural and measurement theory based on common variance, the measurement philosophy is estimation with the common factor model using only common variance (covariances), the research requires a global goodness-of-fit criterion, the error terms require additional specification, such as covariation, the structural model specifies non-recursive relationships or the measurement models are simple (5 or fewer constructs and 50 or fewer indicators) [92,94].

In this study, model fit was evaluated based on the CFI (Comparative Fit Index), the Normed Fit Index (NFI), the Tucker-Lewis coefficient (TLI), RMSEA (Root Mean Square Error of Approximation), and SRMR (Standardized Root Mean Square Residual), whereas the $\chi^{2}$ was used for descriptive purposes only because it is highly sensitive to sample size [99]. The values higher than 0.90 for CFI, NFI, and TLI, and values lower than 0.08 for RMSEA and SRMR, were considered as indicative of a good fit [100]. We considered $p$-values less than 0.05 to be statistically significant [101].

The Shapiro-Wilk test showed the departure from normality for the variables of positive daily functioning $\mathrm{W}(453)=0.986, p<0.001$; positive self-evaluation $\mathrm{W}(453)=0.983$, $p<0.001$; other evaluation of self $\mathrm{W}(453)=0.978, p<0.001$; positive future expectation $W(453)=0.939, p<0.001$; flourishing $W(453)=0.977, p<0.001$; individual attention $W(453)=0.952, p<0.001$; acknowledgement $W(453)=0.954, p<0.001$; assistance $\mathrm{W}(453)=0.951, p<0.001$.

Similarly, the Kolmogorov-Smirnov test showed that data were non-normally distributed for the variables of positive daily functioning $\mathrm{D}(453)=0.057, p=0.001$; positive self-evaluation $\mathrm{D}(453)=0.073, p<0.001$; other evaluation of self $\mathrm{D}(453)=0.110, p<0.001$; positive future expectation $\mathrm{D}(453)=0.159, p<0.001$; flourishing $\mathrm{D}(453)=0.084, p<0.001$; individual attention $\mathrm{D}(453)=0.081, p<0.001$; acknowledgement $\mathrm{D}(453)=0.159, p<0.001$; assistance $\mathrm{D}(453)=0.110, p<0.001$.

The distribution was moderately skewed: positive daily functioning skewness $=-0.116$ $(\mathrm{SE}=0.115)$, kurtosis $=-0.683(\mathrm{SE}=0.229) ;$ positive self-evaluation skewness $=-0.279$ $(\mathrm{SE}=0.115)$, kurtosis $=-0.294(\mathrm{SE}=0.229)$; other evaluation of self skewness $=-0.270$ $(\mathrm{SE}=0.115)$, kurtosis $=-0.460(\mathrm{SE}=0.229)$; positive future expectation skewness $=-0.396$ $(\mathrm{SE}=0.115)$, kurtosis $=-0.376(\mathrm{SE}=0.229)$; flourishing skewness $=-0.435(\mathrm{SE}=0.115)$, kurtosis $=-0.199(\mathrm{SE}=0.229)$; individual attention skewness $=-0.685(\mathrm{SE}=0.115)$, kurtosis $=0.849(\mathrm{SE}=0.229)$; acknowledgement skewness $=-0.484(\mathrm{SE}=0.115)$, kurtosis $=0.828$ $(\mathrm{SE}=0.229)$; assistance skewness $=-0.635(\mathrm{SE}=0.115)$, kurtosis $=0.726(\mathrm{SE}=0.229)$.

\section{Results}

The means, standard deviations, and correlations between the Automatic Thoughts Questionnaire-Positive (ATQP) subscales in this study are reported in Table 2. 
Table 2. The Automatic Thoughts Questionnaire-Positive (ATQP) subscales: descriptive statistics and correlations between the subscales.

\begin{tabular}{cccccc}
\hline The ATQP Variables & $\boldsymbol{M}$ & $\boldsymbol{S D}$ & $\mathbf{1}$ & $\mathbf{2}$ & $\mathbf{3}$ \\
\hline Positive daily functioning & 3.016 & 0.922 & - & & \\
Positive self-evaluation & 3.095 & 0.912 & $0.816^{* * *}$ & - & \\
Other evaluation of self & 3.177 & 0.876 & $0.761^{* * *}$ & $0.715^{* * *}$ & - \\
Positive future expectation & 3.243 & 1.034 & $0.710^{* * *}$ & $0.703^{* * *}$ & $0.620^{* * *}$ \\
\hline mean; $S D$, standard deviation. ${ }^{* * *} p<0.001$ & & &
\end{tabular}

The means, standard deviations, and correlations between the Student-to-Student Confirmation Scale's subscales in this study are reported in Table 3.

Table 3. The Student-to-Student Confirmation Scale's subscales: descriptive statistics and correlations between the subscales.

\begin{tabular}{ccccc}
\hline $\begin{array}{c}\text { The Student-to-Student } \\
\text { Confirmation Scale } \\
\text { Variables }\end{array}$ & $\boldsymbol{M}$ & $\boldsymbol{S D}$ & $\mathbf{1}$ & $\mathbf{2}$ \\
\hline Individual attention & 3.660 & 0.837 & - & - \\
Acknowledgement & 3.255 & 0.836 & $0.668^{* * *}$ & $0.557^{* * *}$ \\
Assistance & 3.522 & 0.856 & $0.688^{* * *}$ &
\end{tabular}

$M$, mean; $S D$, standard deviation. ${ }^{* * *} p<0.001$.

The means, standard deviations, and correlations between the Student-to-Student Confirmation Scale's, Positive Automatic Thoughts scale's and Flourishing scale's in this study are reported in Table 4.

Table 4. Descriptive statistics and correlations between the Automatic Thoughts QuestionnairePositive (ATQP), Flourishing Scale (FS), and Student-to-Student confirmation questionnaire.

\begin{tabular}{ccccc}
\hline Variables & $\boldsymbol{M}$ & $S \boldsymbol{1}$ & $\mathbf{1}$ & $\mathbf{2}$ \\
\hline Positive automatic thoughts & 3.094 & 0.808 & - & \\
(ATQP) & 3.481 & 0.737 & $0.254^{* * *}$ & - \\
Student-to-student confirmation & 3.782 & 0.667 & $0.543^{* * *}$ & $0.276^{* * *}$ \\
Flourishing (FS) &
\end{tabular}

$\bar{M}$, mean; $S D$, standard deviation. ${ }^{* * *} p<0.001$.

To test H1, if computer programming e-learners do not differ in their positive automatic thoughts and self-reported flourishing from other e-learners, we have conducted the independent samples T-test. The results are displayed in Table 5.

Table 5. Comparison of positive automatic thoughts and self-reported flourishing between the groups of participants and non-participants of e-learning based computer programming courses.

\begin{tabular}{|c|c|c|c|c|c|c|c|c|}
\hline & & & & & & & \multicolumn{2}{|c|}{ 95\% CI for Cohen's d } \\
\hline & $\mathbf{t}$ & df & $p$ & Mean Difference & SE Difference & Cohen's d & Lower & Upper \\
\hline $\begin{array}{l}\text { Positive automatic } \\
\text { thoughts (ATQP) }\end{array}$ & -1.447 & 451 & 0.149 & -0.110 & 0.076 & -0.136 & -0.321 & 0.049 \\
\hline $\begin{array}{l}\text { Positive daily } \\
\text { functioning }\end{array}$ & -2.331 & 451 & 0.020 & -0.201 & 0.086 & -0.220 & -0.405 & -0.034 \\
\hline Positive self-evaluation & -0.557 & 451 & 0.578 & -0.048 & 0.086 & -0.052 & -0.237 & 0.132 \\
\hline Other evaluation of self & -1.493 & 451 & 0.133 & -0.123 & 0.082 & -0.141 & -0.325 & 0.044 \\
\hline $\begin{array}{c}\text { Positive future } \\
\text { expectation }\end{array}$ & -1.209 & 451 & 0.277 & -0.118 & 0.097 & -0.114 & -0.299 & 0.071 \\
\hline Flourishing (FS) & -2.965 & 451 & 0.003 & -0.185 & 0.062 & -0.279 & -0.465 & -0.094 \\
\hline
\end{tabular}


Table 7. Cont.

\begin{tabular}{|c|c|c|c|c|c|}
\hline \multirow{2}{*}{ Model } & \multicolumn{2}{|c|}{$\begin{array}{l}\text { Non-Standardized } \\
\text { Coefficients }\end{array}$} & \multirow{2}{*}{$\begin{array}{c}\begin{array}{c}\text { Standardized } \\
\text { Coefficients }\end{array} \\
\text { Beta }\end{array}$} & \multirow{2}{*}{$t$} & \multirow{2}{*}{ Significance } \\
\hline & $B$ & $\begin{array}{l}\text { Standard } \\
\text { Error }\end{array}$ & & & \\
\hline \multicolumn{6}{|l|}{$\begin{array}{l}\text { B. Respondents participate in e-learning-based computer } \\
\text { programming courses }\end{array}$} \\
\hline (Constant) & 2.015 & 0.112 & & 18.068 & $<0.001$ \\
\hline Positive daily functioning & 0.354 & 0.066 & 0.475 & 5.396 & $<0.001$ \\
\hline Positive self-evaluation & -0.042 & 0.059 & -0.056 & -0.718 & 0.474 \\
\hline Other evaluation of self & -0.025 & 0.052 & -0.033 & -0.488 & 0.626 \\
\hline Positive future expectation & 0.268 & 0.043 & 0.414 & 6.240 & $<0.001$ \\
\hline$R=0.762 ; R$ Square $=0.581 ;$ Adjusted $R$ Square $=0.574 ;$ & & & & & \\
\hline
\end{tabular}

A multiple regression model was calculated to predict flourishing based on positive automatic thoughts in groups of respondents participating and not participating in e-learning-based computer programming courses. A significant regression equation was found in the group of respondents participating in computer programming courses, $F(4,237)=82.125, p<0.001)$, with an $R^{2}=0.581$. Respondents' predicted flourishing was equal to $2.015+0.354$ (positive daily functioning) +0.268 (positive future expectation) points. Flourishing increased 0.354 points for each positive daily functioning point and 0.268 points for each positive future expectation point. Positive daily functioning $(B=0.354, p<0.001)$ and positive future expectation $(B=0.268, p<0.001)$ contributed significantly to the model and were significant predictors of flourishing in the group of computer programming e-learners. Additionally, a significant regression equation was found in the group of respondents not participating in computer programming courses, $F(4,206)=6.394, p<0.001)$, with an $R^{2}=0.110$. Respondents' predicted flourishing was equal to $3.242+0.239$ (positive daily functioning) +0.118 (positive future expectation) points. Flourishing increased 0.239 points for each positive daily functioning point and 0.118 points for each positive future expectation point. Positive daily functioning $(B=0.239$, $p=0.006)$ and positive future expectation $(B=0.118, p=0.047)$ contributed significantly to the model and were significant predictors of flourishing in the group of university students who studied social sciences remotely due to the COVID-19 pandemic.

Furthermore, to test $\mathrm{H} 4$, assuming that self-reported flourishing and positive automatic thoughts predict peer-to-peer confirmation of participants and non-participants of e-learning based computer programming courses, we firstly conducted multiple linear regression (forward method) analysis in the group of participants of e-learning based computer programming education. The results are displayed in Table 8.

Table 8. Multiple regression model, the dependent variables are student-to-student confirmation factors, and the predictors are self-reported flourishing and positive automatic thoughts; group of computer programming e-learners.

\begin{tabular}{|c|c|c|c|c|c|c|c|c|c|c|}
\hline \multirow{2}{*}{$\begin{array}{c}\text { Dependent } \\
\text { Variables }\end{array}$} & \multirow{2}{*}{$\begin{array}{l}\text { Predictors/ } \\
\text { Models }\end{array}$} & \multirow{2}{*}{$\begin{array}{c}\text { Unstandardized } \\
\text { Coefficients }\end{array}$} & \multicolumn{2}{|c|}{$\begin{array}{l}\text { Standardized } \\
\text { Coefficients }\end{array}$} & \multirow[t]{2}{*}{$t$} & \multirow[t]{2}{*}{ Sig. } & \multirow[t]{2}{*}{$R$} & \multirow[t]{2}{*}{$R^{2}$} & \multirow[t]{2}{*}{$F$} & \multirow[t]{2}{*}{ Sig. } \\
\hline & & & Std. Error & Beta & & & & & & \\
\hline \multicolumn{11}{|c|}{ Respondents participate in e-learning-based computer programming courses } \\
\hline \multirow{9}{*}{$\begin{array}{l}\text { Student-to- } \\
\text { Student } \\
\text { confirmation }\end{array}$} & 1 (Constant) & 2.484 & 0.138 & \multirow{3}{*}{0.398} & 18.061 & $<0.001$ & \multirow[t]{2}{*}{0.398} & \multirow[t]{2}{*}{0.159} & \multirow[t]{2}{*}{45.283} & \multirow[t]{2}{*}{$<0.001$} \\
\hline & Positive daily functioning & 0.302 & 0.045 & & 6.729 & $<0.001$ & & & & \\
\hline & 2 (Constant) & 2.114 & 0.228 & & 9.270 & $<0.001$ & 0.416 & 0.173 & 24.998 & $<0.001$ \\
\hline & Positive daily functioning & 0.209 & 0.064 & 0.276 & 3.289 & 0.001 & & & & \\
\hline & Flourishing & 0.173 & 0.085 & 0.171 & 2.031 & 0.043 & & & & \\
\hline & 3 (Constant) & 2.027 & 0.227 & & 8.917 & $<0.001$ & 0.445 & 0.198 & 19.591 & $<0.001$ \\
\hline & Positive daily functioning & 0.306 & 0.072 & 0.405 & 4.244 & $<0.001$ & & & & \\
\hline & Flourishing & 0.266 & 0.091 & 0.262 & 2.930 & 0.004 & & & & \\
\hline & Positive future expectation & -0.169 & 0.062 & -0.258 & -2.726 & 0.007 & & & & \\
\hline
\end{tabular}


Table 8. Cont.

\begin{tabular}{|c|c|c|c|c|c|c|c|c|c|c|}
\hline \multirow[t]{2}{*}{$\begin{array}{c}\text { Dependent } \\
\text { Variables }\end{array}$} & \multirow[t]{2}{*}{$\begin{array}{c}\text { Predictors/ } \\
\text { Models }\end{array}$} & \multirow{2}{*}{$\begin{array}{c}\text { Unstandardized } \\
\text { Coefficients }\end{array}$} & \multicolumn{2}{|c|}{$\begin{array}{l}\text { Standardized } \\
\text { Coefficients }\end{array}$} & \multirow[t]{2}{*}{$t$} & \multirow[t]{2}{*}{ Sig. } & \multirow[t]{2}{*}{$R$} & \multirow[t]{2}{*}{$R^{2}$} & \multirow[t]{2}{*}{$F$} & \multirow[t]{2}{*}{ Sig. } \\
\hline & & & Std. Error & Beta & & & & & & \\
\hline \multicolumn{11}{|c|}{ Respondents participate in e-learning-based computer programming courses } \\
\hline \multirow{9}{*}{$\begin{array}{l}\text { Individual } \\
\text { attention }\end{array}$} & 1 (Constant) & 2.034 & 0.275 & & 7.408 & $<0.001$ & 0.339 & 0.115 & 31.114 & $<0.001$ \\
\hline & Flourishing & 0.407 & 0.073 & 0.339 & 5.578 & $<0.001$ & & & & \\
\hline & 2 (Constant) & 1.950 & 0.272 & & 7.157 & $<0.001$ & 0.378 & 0.143 & 19.978 & $<0.001$ \\
\hline & Flourishing & 0.274 & 0.086 & 0.228 & 3.180 & 0.002 & & & & \\
\hline & Other evaluation of self & 0.185 & 0.066 & 0.202 & 2.818 & 0.005 & & & & \\
\hline & 3 (Constant) & 1.771 & 0.280 & & 6.330 & $<0.001$ & 0.405 & 0.164 & 15.529 & $<0.001$ \\
\hline & Flourishing & 0.414 & 0.103 & 0.344 & 4.013 & $<0.001$ & & & & \\
\hline & Other evaluation of self & 0.252 & 0.071 & 0.274 & 3.562 & $<0.001$ & & & & \\
\hline & Positive future expectation & -0.171 & 0.071 & -0.220 & -2.414 & 0.017 & & & & \\
\hline \multirow{2}{*}{ Acknowledgement } & 1 (Constant) & 2.226 & 0.162 & & 13.707 & $<0.001$ & 0.367 & 0.135 & 37.316 & $<0.001$ \\
\hline & Positive daily functioning & 0.323 & 0.053 & 0.367 & 6.109 & $<0.001$ & & & & \\
\hline \multirow{5}{*}{ Assistance } & 1 (Constant) & 2.570 & 0.169 & & 15.171 & $<0.001$ & 0.304 & 0.092 & 24.441 & $<0.001$ \\
\hline & Positive daily functioning & 0.273 & 0.055 & 0.304 & 4.944 & $<0.001$ & & & & \\
\hline & 2 (Constant) & 2.667 & 0.175 & & 15.255 & $<0.001$ & 0.329 & 0.108 & 14.485 & $<0.001$ \\
\hline & Positive daily functioning & 0.400 & 0.083 & 0.446 & 4.830 & $<0.001$ & & & & \\
\hline & Positive future expectation & -0.147 & 0.072 & -0.189 & -2.050 & 0.041 & & & & \\
\hline
\end{tabular}

In the computer programming e-learners, several significant regression equations were found concerning the factor of student-to-student confirmation. In model 1, the dependent variable was student-to-student confirmation, and the predictor was positive daily functioning, $F(1,240)=45.283, p<0.001$, with $R^{2}=0.159$. Predicted student-to-student confirmation was equal to $2.484+0.302$ (positive daily functioning) points. Student-tostudent confirmation increased 0.302 points for each positive daily functioning $(p<0.001)$ point. In model 2 , the dependent variable was student-to-student confirmation, and the predictors were positive daily functioning and flourishing, $F(2,239)=24.998, p<0.001$, with $R^{2}=0.173$. Predicted student-to-student confirmation was equal to $2.114+0.209$ (positive daily functioning) +0.173 (flourishing) points. Student-to-student confirmation increased +0.209 points for each positive daily functioning $(p=0.001)$ point and +0.173 points for each flourishing $(p=0.043)$ point. In model 3 , the dependent variable was studentto-student confirmation, and the predictors were positive daily functioning, flourishing and positive future expectation, $F(3,238)=19.591, p<0.001$, with $R^{2}=0.198$. Predicted student-to-student confirmation was equal to $2.027+0.306$ (positive daily functioning) +0.266 (flourishing) -0.169 (positive future expectation) points. Student-to-student confirmation increased +0.306 points for each positive daily functioning $(p<0.001)$ point, +0.266 points for each flourishing $(p=0.004)$ point and decreased -0.169 for each positive future expectation $(p=0.007)$ point. Thus, positive daily functioning, flourishing and positive future expectation contributed significantly to the model and were significant predictors of student-to-student confirmation in computer programming e-learners.

Likewise, a significant regression equation was found regarding individual attention. In model 1 , the dependent variable was individual attention, and the predictor was flourishing, $F(1,240)=31.114, p<0.001$, with $R^{2}=0.115$. Predicted individual attention was equal to $2.034+0.407$ (flourishing) points. Individual attention increased +0.407 points for each flourishing $(p<0.001)$ point. In model 2 , the dependent variable was individual attention, and the predictors were flourishing and other evaluation of self, $F(2,239)=19,978, p<0.001$, with $R^{2}=0.143$. Predicted individual attention was equal to $1.950+0.274$ (flourishing) +0.185 (other evaluation of self) points. Individual attention increased +0.274 points for each flourishing $(p=0.002)$ point and +0.185 points for each other evaluation of self ( $p=0.005)$ point. In model 3 , the dependent variable was individual attention, and the predictors were flourishing, other evaluation of self and positive future expectation, $F(3,238)=15.529, p<0.001$, with $R^{2}=0.164$. Predicted individual attention was equal to $1.771+0.414$ (flourishing) +0.252 (other evaluation of self) -0.171 (positive 
future expectation) points. Individual attention increased +0.414 points for each flourishing $(p<0.001)$ point, +0.252 points for each other evaluation of self $(p<0.001)$ point and decreased -0.171 points for each positive future expectation $(p=0.017)$ point. Thus, flourishing, other evaluation of self and positive future expectation contributed significantly to the model and were significant predictors of individual attention of computer programming e-learners.

Next, a significant regression equation was found concerning acknowledgement, $F(1,240)=37.316, p<0.001$, with $R^{2}=0.135$. Predicted acknowledgement was equal to $2.226+0.323$ (positive daily functioning) points. Acknowledgement increased +0.323 points for each positive daily functioning $(p<0.001)$ point. So, positive daily functioning was a significant predictor of acknowledgement of computer programming e-learners.

Finally, a significant regression equation was found concerning assistance. In model 1, the dependent variable was assistance, and the predictor was positive daily functioning $F(1,240)=24.441, p<0.001$, with $R^{2}=0.092$. Predicted assistance was equal to $2.570+0.273$ (positive daily functioning) points. Assistance increased +0.273 points for each positive daily functioning $(p<0.001)$ point. In model 2 , the dependent variable was assistance, and the predictors were positive daily functioning and positive future expectation, $F(2,239)=14.485, p<0.001$, with $R^{2}=0.108$. Predicted assistance was equal to $2.667+0.400$ (positive daily functioning) -0.147 (positive future expectation) points. Assistance increased +0.400 points for each daily functioning $(p<0.001)$ point and decreased -0.147 points for each positive future expectation $(p=0.041)$ point. Thus, positive daily functioning and positive future expectation contributed significantly to the model and were significant predictors of assistance in the group of computer programming e-learners.

Next, a multiple linear regression model (enter method) was calculated to predict peerto-peer confirmation based on positive automatic thoughts and flourishing in respondents not participating in e-learning-based computer programming courses. Surprisingly, in this group, no significant regression equations were found. It means, that in the group of social sciences e-learners, differently from computer programming e-learners, positive automatic thoughts and flourishing did not predict peer-to-peer confirmation. The results are displayed in Table 9.

Table 9. Multiple regression model, the dependent variables are student-to-student confirmation factors, and the predictors are self-reported flourishing and positive automatic thoughts; group of social sciences e-learners.

\begin{tabular}{|c|c|c|c|c|c|c|c|c|c|c|}
\hline \multirow{2}{*}{$\begin{array}{l}\text { Dependent } \\
\text { Variables }\end{array}$} & \multirow{2}{*}{$\begin{array}{l}\text { Predictors/ } \\
\text { Models }\end{array}$} & \multirow{2}{*}{$\begin{array}{c}\begin{array}{l}\text { Unstandardized } \\
\text { Coefficients }\end{array} \\
B\end{array}$} & \multicolumn{2}{|c|}{$\begin{array}{l}\text { Standardized } \\
\text { Coefficients }\end{array}$} & \multirow[t]{2}{*}{$t$} & \multirow[t]{2}{*}{ Sig. } & \multirow[t]{2}{*}{$R$} & \multirow[t]{2}{*}{$R^{2}$} & \multirow[t]{2}{*}{$F$} & \multirow[t]{2}{*}{ Sig. } \\
\hline & & & $\begin{array}{l}\text { Std. } \\
\text { Error }\end{array}$ & Beta & & & & & & \\
\hline \multicolumn{11}{|c|}{ Respondents do not participate in e-learning-based computer programming courses } \\
\hline \multirow{6}{*}{$\begin{array}{l}\text { Student-to- } \\
\text { Student } \\
\text { confirmation }\end{array}$} & (Constant) & 2.803 & 0.362 & & 7.738 & $<0.001$ & 0.167 & 0.028 & 1.181 & 0.320 \\
\hline & Positive daily functioning & -0.019 & 0.112 & -0.023 & -0.172 & 0.863 & & & & \\
\hline & Positive self-evaluation & -0.032 & 0.109 & -0.038 & -0.293 & 0.770 & & & & \\
\hline & Other evaluation of self & 0.135 & 0.100 & 0.149 & 1.354 & 0.177 & & & & \\
\hline & $\begin{array}{l}\text { Positive future } \\
\text { expectation }\end{array}$ & 0.003 & 0.076 & 0.004 & 0.037 & 0.971 & & & & \\
\hline & Flourishing & 0.135 & 0.089 & 0.111 & 1.518 & 0.130 & & & & \\
\hline \multirow{6}{*}{$\begin{array}{l}\text { Individual } \\
\text { attention }\end{array}$} & (Constant) & 3.024 & 0.396 & & 7.638 & $<0.001$ & 0.142 & 0.020 & 0.846 & 0.519 \\
\hline & Positive daily functioning & -0.047 & 0.122 & -0.052 & -0.385 & 0701 & & & & \\
\hline & Positive self-evaluation & 0.010 & 0.119 & 0.011 & 0.084 & 0.933 & & & & \\
\hline & Other evaluation of self & 0.110 & 0.109 & 0.111 & 1.011 & 0.313 & & & & \\
\hline & $\begin{array}{l}\text { Positive future } \\
\text { expectation }\end{array}$ & 0.010 & 0.083 & 0.012 & 0.121 & 0.904 & & & & \\
\hline & Flourishing & 0.129 & 0.097 & 0.097 & 1.324 & 0.187 & & & & \\
\hline
\end{tabular}


Table 9. Cont.

\begin{tabular}{|c|c|c|c|c|c|c|c|c|c|c|}
\hline \multirow{2}{*}{$\begin{array}{c}\text { Dependent } \\
\text { Variables }\end{array}$} & \multirow{2}{*}{$\begin{array}{l}\text { Predictors/ } \\
\text { Models }\end{array}$} & \multirow{2}{*}{$\begin{array}{l}\begin{array}{l}\text { Unstandardized } \\
\text { Coefficients }\end{array} \\
\text { B }\end{array}$} & \multicolumn{2}{|c|}{$\begin{array}{c}\text { Standardized } \\
\text { Coefficients }\end{array}$} & \multirow[t]{2}{*}{$t$} & \multirow[t]{2}{*}{ Sig. } & \multirow[t]{2}{*}{$R$} & \multirow[t]{2}{*}{$R^{2}$} & \multirow[t]{2}{*}{$F$} & \multirow[t]{2}{*}{ Sig. } \\
\hline & & & $\begin{array}{l}\text { Std. } \\
\text { Error }\end{array}$ & Beta & & & & & & \\
\hline \multicolumn{11}{|c|}{ Respondents do not participate in e-learning-based computer programming courses } \\
\hline \multirow{6}{*}{$\begin{array}{c}\text { Acknowledge- } \\
\text { ment }\end{array}$} & (Constant) & 2.487 & 0.406 & & 6.119 & $<0.001$ & 0.170 & 0.029 & 1.214 & 0.304 \\
\hline & Positive daily functioning & -0.057 & 0.126 & -0.061 & -0.458 & 0.647 & & & & \\
\hline & Positive self-evaluation & -0.065 & 0.122 & -0.068 & -0.528 & 0.598 & & & & \\
\hline & Other evaluation of self & 0.176 & 0.112 & 0.173 & 1.581 & 0.115 & & & & \\
\hline & $\begin{array}{l}\text { Positive future } \\
\text { expectation }\end{array}$ & 0.029 & 0.085 & 0.034 & 0.342 & 0.732 & & & & \\
\hline & Flourishing & 0.149 & 0.100 & 0.109 & 1.494 & 0.137 & & & & \\
\hline \multirow{6}{*}{ Assistance } & (Constant) & 2.910 & 0.408 & & 7.128 & $<0.001$ & 0.162 & 0.026 & 1.106 & 0.359 \\
\hline & Positive daily functioning & 0.084 & 0.126 & 0.090 & 0.668 & 0.505 & & & & \\
\hline & Positive self-evaluation & -0.053 & 0.123 & -0.056 & -0.432 & 0.666 & & & & \\
\hline & Other evaluation of self & 0.114 & 0.112 & 0.111 & 1.013 & 0.312 & & & & \\
\hline & $\begin{array}{l}\text { Positive future } \\
\text { expectation }\end{array}$ & -0.049 & 0.085 & -0.056 & -0.569 & 0.570 & & & & \\
\hline & Flourishing & 0.124 & 0.100 & 0.091 & 1.243 & 0.215 & & & & \\
\hline
\end{tabular}

Furthermore, to test H5, which assumed that there exist associations between selfreported flourishing, positive automatic thoughts, and student-to-student confirmation, but they differ between participants and non-participants of e-learning based computer programming courses, we have conducted an SEM analysis. Standardized results of the model are presented in Figure 1. Model fit was evaluated based on the CFI (Comparative Fit Index), the Normed Fit Index (NFI), the Tucker-Lewis coefficient (TLI), and RMSEA (Root Mean Square Error of Ap-proximation). As mentioned above, the values higher than 0.90 for CFI, NFI, TLI, and values lower than 0.08 for RMSEA indicate a good fit. Findings revealed that the fit of the model was good, $\chi^{2}=81.320, \mathrm{df}=36, p<0.001 ; \mathrm{NFI}=0.963$; $\mathrm{TLI}=0.967 ; \mathrm{CFI}=0.979 ; \mathrm{RMSEA}=0.075$ [0.053-0.096]; $\mathrm{SRMR}=0.033$.

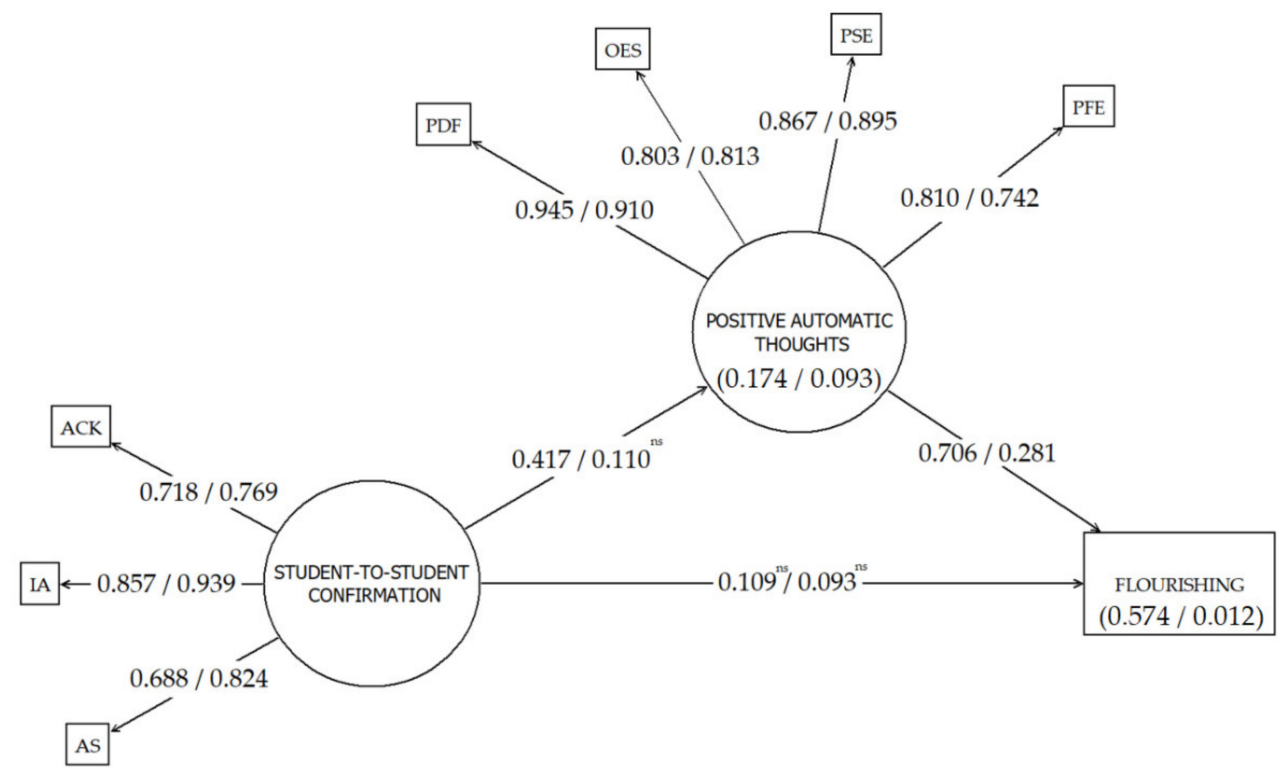

Figure 1. Standardized results of the model on associations between self-reported flourishing, positive automatic thoughts, and student-to-student confirmation in both groups of participants and non-participants of computer programming elearning based courses. ACK: acknowledgement; IA: individual attention; AS: assistance; PDF: positive daily functioning; OES: other evaluation of self; PSE: positive self-evaluation; PFE: positive future expectation: ns: non-significant, parentheses inside the constructs indicate $R^{2}$ values. 
Scalar estimates of the model on associations between self-reported flourishing, positive automatic thoughts, and student-to-student confirmation in both groups of participants and non-participants of computer programming e-learning based courses are presented in Table 10.

Table 10. Scalar estimates of the model on associations between self-reported flourishing, positive automatic thoughts, and student-to-student confirmation in groups of participants and non-participants of computer programming e-learning based courses.

\begin{tabular}{|c|c|c|c|c|c|c|c|c|c|c|c|}
\hline \multicolumn{3}{|c|}{ Regression } & \multirow{2}{*}{$\begin{array}{c}\text { B } \\
0.623\end{array}$} & \multirow{2}{*}{$\begin{array}{l}\text { S.E. } \\
0.114\end{array}$} & \multirow{2}{*}{$\begin{array}{c}\mathrm{Z} \\
5.485\end{array}$} & \multirow{2}{*}{$\begin{array}{c}p \\
<0.001\end{array}$} & \multirow{2}{*}{$\begin{array}{c}\text { LL } \\
0.400\end{array}$} & \multirow{2}{*}{$\begin{array}{c}\text { UL } \\
0.845\end{array}$} & \multirow{2}{*}{$\begin{array}{c}\beta \\
0.417\end{array}$} & \multirow{2}{*}{$\begin{array}{c}R^{2} \\
0.174\end{array}$} & \multirow{2}{*}{$\begin{array}{c}\text { Group * } \\
1\end{array}$} \\
\hline $\begin{array}{l}\text { Student-to-student } \\
\text { confirmation }\end{array}$ & $\rightarrow$ & $\begin{array}{c}\text { Positive } \\
\text { automatic } \\
\text { thoughts }\end{array}$ & & & & & & & & & \\
\hline $\begin{array}{l}\text { Positive automatic } \\
\text { thoughts }\end{array}$ & $\rightarrow$ & Flourishing & 0.557 & 0.048 & 11.697 & $<0.001$ & 0.464 & 0.650 & 0.706 & 0.574 & 1 \\
\hline $\begin{array}{l}\text { Student-to-student } \\
\text { confirmation }\end{array}$ & $\rightarrow$ & Flourishing & 0.128 & 0.089 & 1.434 & 0.151 & -0.047 & 0.303 & 0.109 & & 1 \\
\hline $\begin{array}{l}\text { Student-to-student } \\
\text { confirmation }\end{array}$ & $\rightarrow$ & $\begin{array}{c}\text { Positive } \\
\text { automatic } \\
\text { thoughts }\end{array}$ & 0.139 & 0.116 & 1.192 & 0.233 & -0.089 & 0.367 & 0.110 & 0.093 & 2 \\
\hline $\begin{array}{l}\text { Positive automatic } \\
\text { thoughts }\end{array}$ & $\rightarrow$ & Flourishing & 0.212 & 0.059 & 3.609 & $<0.001$ & 0.097 & 0.327 & 0.281 & 0.012 & 2 \\
\hline $\begin{array}{l}\text { Student-to-student } \\
\text { confirmation }\end{array}$ & $\rightarrow$ & Flourishing & 0.089 & 0.068 & 1.305 & 0.192 & -0.045 & 0.222 & 0.093 & & 2 \\
\hline
\end{tabular}

\begin{tabular}{|c|c|c|c|c|c|c|c|c|c|c|c|}
\hline \multicolumn{12}{|c|}{ Measurement Model } \\
\hline $\begin{array}{l}\text { Positive automatic } \\
\text { thoughts }\end{array}$ & $\rightarrow$ & $\begin{array}{l}\text { Positive daily } \\
\text { functioning }\end{array}$ & 1.000 & 0.000 & & & 1.000 & 1.000 & 0.945 & 0.894 & 1 \\
\hline $\begin{array}{l}\text { Positive automatic } \\
\text { thoughts }\end{array}$ & $\rightarrow$ & $\begin{array}{c}\text { Other } \\
\text { evaluation of } \\
\text { self }\end{array}$ & 0.831 & 0.044 & 18.907 & $<0.001$ & 0.745 & 0.917 & 0.803 & 0.646 & 1 \\
\hline $\begin{array}{l}\text { Positive automatic } \\
\text { thoughts }\end{array}$ & $\rightarrow$ & $\begin{array}{c}\text { Positive } \\
\text { self-evaluation }\end{array}$ & 0.913 & 0.045 & 20.410 & $<0.001$ & 0.825 & 1.000 & 0.867 & 0.751 & 1 \\
\hline $\begin{array}{l}\text { Positive automatic } \\
\text { thoughts }\end{array}$ & $\rightarrow$ & $\begin{array}{l}\text { Positive future } \\
\text { expectation }\end{array}$ & 0.989 & 0.055 & 18.033 & $<0.001$ & 0.881 & 1.096 & 0.810 & 0.657 & 1 \\
\hline $\begin{array}{l}\text { Student-to-student } \\
\text { confirmation }\end{array}$ & $\rightarrow$ & Acknowledgeme & htl.000 & 0.000 & & & 1.000 & 1.000 & 0.718 & 0.515 & 1 \\
\hline $\begin{array}{l}\text { Student-to-student } \\
\text { confirmation }\end{array}$ & $\rightarrow$ & $\begin{array}{l}\text { Individual } \\
\text { attention }\end{array}$ & 1.215 & 0.128 & 9.472 & $<0.001$ & 0.963 & 1.466 & 0.857 & 0.735 & 1 \\
\hline $\begin{array}{l}\text { Student-to-student } \\
\text { confirmation }\end{array}$ & $\rightarrow$ & Assistance & 0.976 & 0.112 & 8.704 & $<0.001$ & 0.756 & 1.195 & 0.688 & 0.473 & 1 \\
\hline $\begin{array}{l}\text { Positive automatic } \\
\text { thoughts }\end{array}$ & $\rightarrow$ & $\begin{array}{l}\text { Positive daily } \\
\text { functioning }\end{array}$ & 1.000 & 0.000 & & & 1.000 & 1.000 & 0.910 & 0.828 & 2 \\
\hline $\begin{array}{l}\text { Positive automatic } \\
\text { thoughts }\end{array}$ & $\rightarrow$ & $\begin{array}{c}\text { Other } \\
\text { evaluation of } \\
\text { self }\end{array}$ & 0.823 & 0.042 & 19.398 & $<0.001$ & 0.740 & 0.906 & 0.813 & 0.660 & 2 \\
\hline $\begin{array}{l}\text { Positive automatic } \\
\text { thoughts }\end{array}$ & $\rightarrow$ & $\begin{array}{c}\text { Positive } \\
\text { self-evaluation }\end{array}$ & 0.978 & 0.045 & 21.676 & $<0.001$ & 0.889 & 1.066 & 0.895 & 0.800 & 2 \\
\hline $\begin{array}{l}\text { Positive automatic } \\
\text { thoughts }\end{array}$ & $\rightarrow$ & $\begin{array}{l}\text { Positive future } \\
\text { expectation }\end{array}$ & 0.891 & 0.074 & 12.081 & $<0.001$ & 0.746 & 1.035 & 0.742 & 0.551 & 2 \\
\hline $\begin{array}{l}\text { Student-to-student } \\
\text { confirmation }\end{array}$ & $\rightarrow$ & Acknowledgemer & htl.000 & 0.000 & & & 1.000 & 1.000 & 0.769 & 0.591 & 2 \\
\hline $\begin{array}{l}\text { Student-to-student } \\
\text { confirmation }\end{array}$ & $\rightarrow$ & $\begin{array}{l}\text { Individual } \\
\text { attention }\end{array}$ & 1.184 & 0.098 & 12.066 & $<0.001$ & 0.992 & 1.377 & 0.939 & 0.881 & 2 \\
\hline $\begin{array}{l}\text { Student-to-student } \\
\text { confirmation }\end{array}$ & $\rightarrow$ & Assistance & 1.076 & 0.089 & 12.070 & $<0.001$ & 0.901 & 1.250 & 0.824 & 0.680 & 2 \\
\hline
\end{tabular}
* Group 1: participants of e-learning based computer programming courses; Group 2: non-participants of e-learning based computer programming courses.

The SEM analysis showed that student-to-student confirmation does not predict flourishing in both sample groups. Student-to-student confirmation statistically significantly 
predicts positive automatic thoughts only in the computer programming e-learners group, and student-to-student confirmation explains $17.4 \%$ of the variance of positive automatic thoughts. Positive automatic thoughts statistically significantly predict flourishing in both sample groups. Student-to-student confirmation and positive automatic thoughts explain $57.4 \%$ of the variance of flourishing in the computer programming e-learners group and $9.3 \%$ in the social sciences e-learners group.

\section{Discussion}

This study was the first to explore associations between positive automatic thoughts, self-reported psychological flourishing, and peer-to-peer confirmation in e-learning-based education, including computer programming learning, during the COVID-19 pandemic. The relationship between peer-to-peer confirmation and mental health has been extensively studied $[30,34,35,79]$. Most of the previous studies targeted educational variables, such as learning motivation $[34,35]$ and mental health indicators, such as depression and anxiety [1], with a narrow focus on psychological wellbeing [79]. This study primarily targeted the positive psychology construct of flourishing and positive automatic thoughts in relation to peer-to-peer confirmation in e-learning. The examination of positive automatic thoughts was based on a model developed by Ingram and Wisnicki [17]; the examination of flourishing was based on a model developed by Diener et al. [42], and the examination of peer-to-peer confirmation was based on a model developed by LaBelle and Johnson [35]. The context of the COVID-19 quarantine, which brought the rapid implementation of elearning [80], helped us compare positive automatic thoughts, self-reported psychological flourishing, and peer-to-peer confirmation in e-learning-based computer programming education and e-learning education in social sciences. It also revealed some specifics of associations between the study variables in different samples.

\subsection{Computer Programming E-Learners Differ from Other E-Learners in Flourishing and Positive Daily Functioning}

In this study, we assumed (H1) that computer programming e-learners do not differ in their positive automatic thoughts and self-reported flourishing from other e-learners. This assumption was based on previous research indicating that computer programming learners do not demonstrate higher scores on personality trait neuroticism [78], which is related to negative thoughts [102] and diminished flourishing [103,104]. Thus, we have conducted the independent samples T-test and compared the scores of positive automatic thoughts and self-reported flourishing in both groups. The results partially confirmed this hypothesis, as no significant differences between the groups were found in positive automatic thoughts, positive self-evaluation, other evaluation of self, and positive future expectations. However, T-test analysis has revealed some significant differences between the samples. Surprisingly, university students who studied social sciences demonstrated higher scores of positive daily functioning and flourishing than participants of e-learning based computer programming education. These results might be partially explained by previous research suggesting that flourishing is related to social wellbeing $[42,45,47,49,105]$. However, it is unclear why computer programming e-learners differed from e-learners in social sciences in flourishing and positive daily functioning but did not differ in positive automatic thoughts, positive self-evaluation, other evaluation of self, and positive future expectation. Due to the relatively small sample size, these findings should be taken with caution and needs further investigation, especially establishing links between positive psychology constructs, personality traits, and objective indicators.

\subsection{Computer Programming E-Learners Differ in Their Peer-to-Peer Confirmation from Other E-Learners}

Furthermore, we presumed $(\mathrm{H} 2)$ that computer programming e-learners differ in their peer-to-peer confirmation from other e-learners. This assumption was based on previous research which revealed that computer programming e-learners demonstrated lower scores of extraversion [78], which is linked to social connectedness [106]. Hence, 
we conducted the independent samples' T-test, which revealed statistically significant differences between the groups. As expected, non-participants of computer programming e-learning courses demonstrated higher scores of a peer-to-peer confirmation than participants of computer programming e-learning courses. University students in social sciences demonstrated higher scores of individual attention than participants of e-learning based computer programming education. In addition, non-participants demonstrated higher scores of acknowledgement than computer programming e-learners. Moreover, non-participants of e-learning based computer programming education demonstrated higher scores of assistance in comparison to participants. These studies align with prior research on personality traits and social connectedness [106,107]. However, as this study did not directly link personality traits to peer-to-peer confirmation, these results must be regarded with caution and need further examination.

\subsection{Positive Automatic Thoughts Partially Predict the Flourishing of Computer Programming and} Other E-Learners

Next, we assumed (H3) that positive automatic thoughts predict self-reported flourishing in both groups of participants and non-participants of e-learning based computer programming courses. This assumption was based on positive psychology and cognitive behaviour therapy research, evidencing that thoughts affect psychological wellbeing $[106,108,109]$. Hence, we conducted multiple linear regression analyses, which showed that in the group of students of computer-based e-learning education and in the group of university students who studied social sciences remotely due to the COVID-19 pandemic, positive daily functioning and positive future expectation predicted self-reported flourishing. These findings support extensive studies suggesting links between positive thoughts and psychological wellbeing [106,108-111]. However, it is unclear why flourishing was predicted just by positive daily functioning and positive future expectations. This study indicated no significant effects of positive self-evaluation and other evaluations of self, which are also indicators of positive automatic thoughts [17]. Therefore, these results need further investigation.

\subsection{Positive Automatic Thoughts and Flourishing Predict Peer-to-Peer Confirmation in Group of Computer Programming E-Learners}

Furthermore, we presumed (H4) that self-reported flourishing and positive automatic thoughts predict peer-to-peer confirmation of participants and non-participants of e-learning based computer programming courses. This premise was based on previous research indicating that peer-to-peer confirmation and interactions are linked to the positive effect for the course, the instructor, and the content [33,35,112], greater mental well-being among college students [110] and in other contexts [113]. Therefore, we conducted multiple linear regression analysis, which showed that in the group of computer programming e-learners, peer-to-peer confirmation was predicted by positive daily functioning (model 1), positive daily functioning and flourishing (model 2), positive daily functioning, flourishing, and positive future expectations (model 3). Likewise, individual attention was predicted by flourishing (model 1), flourishing and other evaluation of self (model 2), flourishing, other evaluation of self and positive future expectations (model 3). Next, acknowledgement was predicted by positive daily functioning. Finally, assistance was predicted by positive daily functioning (model 1), positive daily functioning and positive future expectations (model 2). These results support previous findings suggesting links between interpersonal interactions, positive thinking and wellbeing [33,35,42,49,79,105,110,112,113]. Surprisingly, no significant regression equations were found in the group of respondents not participating in e-learning-based computer programming courses. It means that in the group of social sciences e-learners, differently from computer programming e-learners, positive automatic thoughts and flourishing did not predict peer-to-peer confirmation. These findings partially contradict some previously mentioned studies, which evidenced links between peer support, thinking patterns, and psychological wellbeing, and need further examination. 


\subsection{Associations between the Study Variables Partially Differ in the Compared Groups}

Based on a literature review and previous analyses, we assumed (H5) that associations between self-reported flourishing, positive automatic thoughts, and peer-to-peer confirmation exist, but they differ between participants and non-participants of e-learning based computer programming courses. Thus, we tested several models of associations between these study variables. The findings partially confirmed the hypothesis and identified several possible paths and models of associations between self-reported flourishing, positive automatic thoughts, and peer-to-peer confirmation in groups of participants and non-participants of e-learning-based computer programming courses. The SEM analysis revealed that peer-to-peer confirmation did not predict flourishing in both sample groups. Peer-to-peer confirmation statistically significantly predicted positive automatic thoughts only in the computer programming e-learners group, and in this group, peer-to-peer confirmation explained $17.4 \%$ of the variance of positive automatic thoughts. Positive automatic thoughts statistically significantly predicted flourishing in both sample groups. Peer-to-peer confirmation and positive automatic thoughts explained $57.4 \%$ of the variance of flourishing in the computer programming e-learners group and $9.3 \%$ of the flourishing variance in the social sciences e-learners group. These results signify the importance of peer-to-peer confirmation and positive thoughts for computer programming e-learners' psychological wellbeing.

To summarize, this study demonstrated that associations between self-reported flourishing, positive automatic thoughts, and peer-to-peer confirmation differ between participants and non-participants of e-learning-based computer programming courses. The effect of peer-to-peer confirmation and positive thoughts was almost six times larger for computer programming e-learners.

The findings on associations between self-reported flourishing, positive automatic thoughts, and peer-to-peer confirmation are consistent with many previous studies suggesting the links between positive automatic thoughts, psychological wellbeing, and peer connectedness [33,35,79,105,110,112-115]. However, the mechanism underlying the links' specifics in different samples is still unclear and needs further investigation. In the future, it would be essential to identify the underlying mechanisms in associations between peerto-peer confirmation factors and the positive states of computer programming e-learners.

\subsection{Theoretical Implications}

From a theoretical perspective, this study was the first of its kind to explore the associations between positive automatic thoughts, self-reported psychological flourishing, and peer-to-peer confirmation in e-learning-based education, including computer programming learning, during the COVID-19 pandemic. From a perspective of sustainability, well-being is a key sustainable development goal [116], and this study adds to the psychology of sustainability and sustainable development, which highlight sustainable development of every person, facilitating the flourishing of his/her intrapersonal talents and also emphasizes well-being in different kinds of environments [116].

Even though the relationship between peer-to-peer confirmation and mental health has been broadly researched, most of the previous studies targeted educational variables and mental health indicators, with a limited focus on psychological wellbeing [1,79]. This study primarily targeted the positive psychology construct of flourishing and positive automatic thoughts. The findings were consistent with previous studies suggesting associations between the positive automatic thoughts, self-reported psychological flourishing, and peer-to-peer confirmation $[33,35,79,105,110,112-115]$, and it also revealed the complexity of the relations between positive automatic thoughts, self-reported psychological flourishing, and peer-to-peer confirmation in groups of computer programming and social sciences elearners. It is unclear why the effect of peer-to-peer confirmation and positive thoughts was almost six times larger for computer programming e-learners, and why positive automatic thoughts and flourishing predicted peer-to-peer confirmation just in group of computer programming e-learners. It is also unclear why flourishing was predicted just by positive 
daily functioning and positive future expectations, and not by positive self-evaluation and other evaluation of self, which are also indicators of positive automatic thoughts [17]. In the future, it would be valuable to identify the computer programming and other e-learners' underlying mechanisms in associations between peer-to-peer confirmation factors and positive states, which have recently received the increased attention of researchers [117], as a constructive change of beliefs (attitudes, knowledge, information structures) and, consequently, behaviours are central to reach sustainable development goals and facilitate personal and environmental flourishing [116].

\subsection{Practical Implications}

Research indicates that due to the COVID-19 pandemic, online learning has been adopted in all stages of education, and this sudden change could affect students' learning effectiveness $[8,80,118]$. Computer programming education also faced challenges that affected the world during the quarantine [1]. Some students developed emotional difficulties related to stressful life circumstances [9], which affected satisfaction with e-learning [10], or led to diminished e-learning motivation or even absence of it [11] However, the cognitive model of emotional difficulties suggests that psychological wellbeing mainly depend not on life circumstances themselves [12], but on cognitive processes, which may manifest in positive or negative automatic thoughts [13-16]. Positive automatic thoughts promote psychological well-being [17], which is linked to many positive educational outcomes [23,24]. This study explored the role of cognitive specificity of beliefs in self-reported psychological flourishing and peer-to-peer confirmation. The results revealed that positive automatic thoughts significantly contribute to the flourishing of e-learners and promote peer-to-peer confirmation of computer programming e-learners. The findings on associations between positive automatic thoughts, self-reported psychological flourishing, and peer-to-peer confirmation in e-learning based education imply that education policymakers, researchers, and educators, to promote learners' flourishing, which is linked to academic achievements [23,24], should target e-learners' beliefs and peer-to-peer confirmation. Focus on e-learners' beliefs and flourishing would also assist in promoting the sustainable happiness of a person and society as the whole, as sustainability is defined not only in terms of the ecological and socio-economic environment but also in terms of improving the quality of life of every human being [116] and introduces a framework focused on a positive approach based on keywords such as promotion, enrichment, growth, flexible change [119].

\subsection{Limitations and Future Directions}

Several limitations to this study can be revealed. First, this study lacks a solid unifying theoretical basis because it applied constructs based on different theoretical models. Second, bias may have occurred due to using self-reported measures only and the omission of objective indicators. Third, considering that the data were collected online, these findings should be regarded with caution. Fourth, the research samples were not representative, suggesting the necessity to analyze representative samples of e-learners; thus, generalizations should be made with concern. Next, although the sample size satisfied the minimal requirements for the applied statistical models, and the data fit was acceptable, the results should be regarded cautiously due to the relatively small sample size. Furthermore, this study was conducted in Lithuania, and the results may reflect the cultural specifics of this area, suggesting the necessity to analyze the impact of cultural factors, considering the more specific aspects of each culture. Finally, the findings suggest a necessity for longitudinal or experimental research design because, based on the data obtained, it is possible only to identify significant relationships among the examined variables. Thus, the conclusions should be cautioned, especially regarding causality, because reverse causality is also likely to occur. 


\section{Conclusions}

This study targeted positive automatic thoughts, self-reported psychological flourishing, and peer-to-peer confirmation of computer programming e-learners. The findings revealed that computer programming e-learners differed from other e-learners in flourishing, positive daily functioning, and peer-to-peer confirmation. In both samples, positive daily functioning and positive future expectations predicted self-reported flourishing. Positive automatic thoughts and flourishing predicted peer-to-peer confirmation just in the group of computer programming e-learners. Peer-to-peer confirmation and positive automatic thoughts explained $57.4 \%$ of the variance of flourishing in the computer programming e-learners group and $9.3 \%$ of the flourishing variance in the social sciences e-learners group. These results signify the importance of peer-to-peer confirmation and positive thoughts for computer programming e-learners' psychological wellbeing. Nevertheless, the results of this particular study should be regarded with caution due to the relatively small sample size and other limitations.

Author Contributions: Conceptualization, A.D., A.P., Ž.S.-P. and J.Š.; methodology, A.D., A.V. and A.P.; software, L.K., G.Ž. and K.M.; validation, A.D. and A.V.; formal analysis, A.D. and A.V.; investigation, A.D., A.V. and A.P.; resources, A.D. and L.K.; data curation, A.V.; writing—original draft preparation, A.D., Ž.S.-P., J.Š. and A.V.; writing—review and editing, A.D.; visualization, A.V.; supervision, A.D. All authors have read and agreed to the published version of the manuscript.

Funding: This research was funded by LVPA, project number S-01.2.1-LVPA-K-856-01-0238.

Institutional Review Board Statement: The study was conducted according to the guidelines of the Declaration of Helsinki and approved by the Institute of Management and Psychology.

Informed Consent Statement: Informed consent was obtained from all subjects involved in the study.

Data Availability Statement: The data that support the findings of this study are available from the corresponding author, upon reasonable request.

Acknowledgments: The authors acknowledge technical support of Turing College professionals, https: / / www.turingcollege.com (accessed on 7 September 2021).

Conflicts of Interest: The authors declare no conflict of interest.

\section{References}

1. Dirzyte, A.; Vijaikis, A.; Perminas, A.; Rimasiute-knabikiene, R. Associations between Depression, Anxiety, Fatigue, and Learning Motivating Factors in e-Learning-Based Computer Programming Education. Int. J. Environ. Res. Public Health 2021, 18, 9158. [CrossRef] [PubMed]

2. Escudero-Castillo, I.; Mato-Díaz, F.J.; Rodriguez-Alvarez, A. Furloughs, Teleworking and Other Work Situations during the COVID-19 Lockdown: Impact on Mental Well-Being. Int. J. Environ. Res. Public Health 2021, 18, 2898. [CrossRef] [PubMed]

3. Lawrence, S.A.; Garcia, J.; Stewart, C.; Rodriguez, C. The mental and behavioral health impact of COVID-19 stay at home orders on social work students. Soc. Work Educ. 2021, 1-15. [CrossRef]

4. Chadee, D.; Ren, S.; Tang, G. Is digital technology the magic bullet for performing work at home? Lessons learned for post COVID-19 recovery in hospitality management. Int. J. Hosp. Manag. 2021, 92, 102718. [CrossRef] [PubMed]

5. Yan, S.; Xu, R.; Stratton, T.D.; Kavcic, V.; Luo, D.; Hou, F.; Bi, F.; Jiao, R.; Song, K.; Jiang, Y. Sex differences and psychological stress: Responses to the COVID-19 pandemic in China. BMC Public Health 2021, 21, 79. [CrossRef] [PubMed]

6. Kanzler, K.E.; Ogbeide, S. Addressing trauma and stress in the COVID-19 pandemic: Challenges and the promise of integrated primary care. Psychol. Trauma Theory Res. Pract. Policy 2020, 12, S177-S179. [CrossRef] [PubMed]

7. Afulani, P.A.; Gyamerah, A.O.; Nutor, J.J.; Laar, A.; Aborigo, R.A.; Malechi, H.; Sterling, M.; Awoonor-Williams, J.K. Inadequate preparedness for response to COVID-19 is associated with stress and burnout among healthcare workers in Ghana. PLoS ONE 2021, 16, e0250294. [CrossRef]

8. Bond, M.; Bedenlier, S.; Marín, V.I.; Händel, M. Emergency remote teaching in higher education: Mapping the first global online semester. Int. J. Educ. Technol. High. Educ. 2021, 18, 50. [CrossRef]

9. Othman, N.; Ahmad, F.; El Morr, C.; Ritvo, P. Perceived impact of contextual determinants on depression, anxiety and stress: A survey with university students. Int. J. Ment. Health Syst. 2019, 13, 17. [CrossRef]

10. Fawaz, M.; Samaha, A. E-learning: Depression, anxiety, and stress symptomatology among Lebanese university students during COVID-19 quarantine. Nurs. Forum 2021, 56, 52-57. [CrossRef] 
11. Al-Tammemi, A.B.; Akour, A.; Alfalah, L. Is It Just About Physical Health? An Online Cross-Sectional Study Exploring the Psychological Distress Among University Students in Jordan in the Midst of COVID-19 Pandemic. Front. Psychol. 2020, 11, 562213. [CrossRef]

12. Beck, A.T. Theoretical perspectives on clinical anxiety. In Anxiety and the Anxiety Disorders; Lawrence Erlbaum Associates, Inc.: Hillsdale, NJ, USA, 1985; pp. 183-196, ISBN 0-89859-532-0.

13. Borkovec, T.D.; Inz, J. The nature of worry in generalized anxiety disorder: A predominance of thought activity. Behav. Res. Ther. 1990, 28, 153-158. [CrossRef]

14. Reiss, S. Expectancy model of fear, anxiety, and panic. Clin. Psychol. Rev. 1991, 11, 141-153. [CrossRef]

15. Ehlers, A.; Clark, D.M. A cognitive model of posttraumatic stress disorder. Behav. Res. Ther. 2000, 38, 319-345. [CrossRef]

16. Clark, D.A.; Beck, A.T. Cognitive Therapy of Anxiety Disorders: Science and Practice; Guilford Press: New York, NY, USA, 2010; ISBN 978-1-60623-434-1.

17. Ingram, R.E.; Wisnicki, K.S. Assessment of positive automatic cognition. J. Consult. Clin. Psychol. 1988, 56, 898-902. [CrossRef]

18. Lightsey, O.R. "Thinking positive" as a stress buffer: The role of positive automatic cognitions in depression and happiness. J. Couns. Psychol. 1994, 41, 325-334. [CrossRef]

19. Berndt, E.R.; Koran, L.M.; Finkelstein, S.N.; Gelenberg, A.J.; Kornstein, S.G.; Miller, I.M.; Thase, M.E.; Trapp, G.A.; Keller, M.B. Lost human capital from early-onset chronic depression. Am. J. Psychiatry 2000, 157, 940-947. [CrossRef]

20. Zivcic-Becirevic, I. The Role of Automatic Thoughts and Test Anxiety in University Students' Achievements. Drus. Istraz. 2003, $12,703-720$.

21. Fletcher, J.M. Adolescent depression: Diagnosis, treatment, and educational attainment. Health Econ. 2008, 17, 1215-1235. [CrossRef]

22. Maric, M.; Heyne, D.A.; de Heus, P.; van Widenfelt, B.M.; Westenberg, P.M. The Role of Cognition in School Refusal: An Investigation of Automatic Thoughts and Cognitive Errors. Behav. Cogn. Psychother. 2012, 40, 255-269. [CrossRef]

23. Antaramian, S. Assessing Psychological Symptoms and Well-Being: Application of a Dual-Factor Mental Health Model to Understand College Student Performance. J. Psychoeduc. Assess. 2015, 33, 419-429. [CrossRef]

24. Howell, A.J. Flourishing: Achievement-related correlates of students' well-being. J. Posit. Psychol. 2009, 4, 1-13. [CrossRef]

25. Stuart, A. Student-centered learning. Learning 1997, 26, 53-56.

26. McCombs, B.; Whisler, J.S. The Learner-Centered Classroom and School: Strategies for Increasing Student Motivation and Achievement; The Jossey-Bass Education Series; Jossey-Bass Inc.: San Francisco, CA, USA, 1997.

27. Weimer, M. Learner-Centered Teaching: Five Key Changes to Practice; Jossey-Bass: San Francisco, CA, USA, 2002.

28. Shikulo, L.; Lekhetho, M. Exploring student support services of a distance learning centre at a Namibian university. Cogent Soc. Sci. 2020, 6, 1737401. [CrossRef]

29. Sánchez-Elvira Paniagua, A.; Simpson, O. Developing Student Support for Open and Distance Learning: The EMPOWER Project. J. Interact. Media Educ. 2018, 2018. [CrossRef]

30. Dwyer, K.K.; Bingham, S.G.; Carlson, R.E.; Prisbell, M.; Cruz, A.M.; Fus, D.A. Communication and connectedness in the classroom: Development of the connected classroom climate inventory. Commun. Res. Rep. 2004, 21, 264-272. [CrossRef]

31. Goodboy, A.K. The Development and Validation of the Instructional Dissent Scale. Commun. Educ. 2011, 60, 422-440. [CrossRef]

32. Sidelinger, R.J.; Booth-Butterfield, M. Co-constructing Student Involvement: An Examination of Teacher Confirmation and Student-to-Student Connectedness in the College Classroom. Commun. Educ. 2010, 59, 165-184. [CrossRef]

33. Sollitto, M.; Johnson, Z.D.; Myers, S.A. Students' Perceptions of College Classroom Connectedness, Assimilation, and Peer Relationships. Commun. Educ. 2013, 62, 318-331. [CrossRef]

34. Johnson, Z.D.; LaBelle, S. Student-to-Student Confirmation in the College Classroom: An Initial Investigation of the Dimensions and Outcomes of Students' Confirming Messages. Commun. Educ. 2016, 65, 44-63. [CrossRef]

35. LaBelle, S.; Johnson, Z.D. Student-to-student confirmation in the college classroom: The development and validation of the Student-to-Student Confirmation Scale. Commun. Educ. 2018, 67, 185-205. [CrossRef]

36. Johnson, Z.D.; LaBelle, S. Confirmation in the college classroom: The connections between teacher's use of confirming messages and student's own communicative behaviors. Commun. Res. Rep. 2020, 37, 172-181. [CrossRef]

37. Sieburg, E. Interpersonal Confirmation: A Paradigm for Conceptualization and Measurement. Paper presented at the annual meeting of the International Communication Association, Montreal, QC, Canada, 25-29 April 1973.

38. Ellis, K. Perceived teacher confirmation: The development and validation of an instrument and two studies of the relationship to cognitive and affective learning. Hum. Commun. Res. 2000, 26, 264-291. [CrossRef]

39. Goodboy, A.K.; Myers, S.A. The Effect of Teacher Confirmation on Student Communication and Learning Outcomes. Commun. Educ. 2008, 57, 153-179. [CrossRef]

40. Mazer, J.P. Validity of the Student Interest and Engagement Scales: Associations with Student Learning Outcomes. Commun. Stud. 2013, 64, 125-140. [CrossRef]

41. LaBelle, S.; Johnson, Z.D. The relationship of student-to-student confirmation and student engagement. Commun. Res. Rep. 2020, 37, 234-242. [CrossRef]

42. Diener, E.; Wirtz, D.; Tov, W.; Kim-Prieto, C.; Choi, D.; Oishi, S.; Biswas-Diener, R. New Well-being Measures: Short Scales to Assess Flourishing and Positive and Negative Feelings. Soc. Indic. Res. 2010, 97, 143-156. [CrossRef] 
43. Keyes, C.L.M.; Lopez, S.J. Toward a science of mental health: Positive directions in diagnosis and interventions. In Handbook of Positive Psychology; Oxford University Press: New York, NY, USA, 2002; pp. 45-59, ISBN 0-19-513533-4.

44. Huppert, F.A. Psychological Well-being: Evidence Regarding its Causes and Consequences. Appl. Psychol. Health Well-Being 2009, 1, 137-164. [CrossRef]

45. Keyes, C.L.M. The Mental Health Continuum: From Languishing to Flourishing in Life. J. Health Soc. Behav. 2002, 43, 207. [CrossRef]

46. Ryff, C.D.; Singer, B. The Contours of Positive Human Health. Psychol. Inq. 1998, 9, 1-28. [CrossRef]

47. Huppert, F.A.; So, T.T.C. Flourishing Across Europe: Application of a New Conceptual Framework for Defining Well-Being. Soc. Indic. Res. 2013, 110, 837-861. [CrossRef]

48. Keyes, C.L.M. Mental Illness and/or Mental Health? Investigating Axioms of the Complete State Model of Health. J. Consult. Clin. Psychol. 2005, 73, 539-548. [CrossRef]

49. Seligman, M.E.P. Flourish: A Visionary New Understanding of Happiness and Well-Being; Simon \& Schuster: New York, NY, USA, 2011; Volume 27.

50. Hone, L.C.; Jarden, A.; Schofield, G.M.; Duncan, S. Measuring flourishing: The impact of operational definitions on the prevalence of high levels of wellbeing. Int. J. Wellbeing 2014, 4, 62-90. [CrossRef]

51. Volstad, C.; Hughes, J.; Jakubec, S.L.; Flessati, S.; Jackson, L.; Martin-Misener, R. "You have to be okay with okay": Experiences of flourishing among university students transitioning directly from high school. Int. J. Qual. Stud. Health Well-Being 2020, 15, 1834259. [CrossRef]

52. Fink, J.E. Flourishing: Exploring Predictors of Mental Health Within the College Environment. J. Am. Coll. Health 2014, 62, 380-388. [CrossRef]

53. Bowman, N.; Brandenberger, J.; Lapsley, D.; Hill, P.; Quaranto, J. Serving in College, Flourishing in Adulthood: Does Community Engagement During the College Years Predict Adult Well-Being? Appl. Psychol. Health Well-Being 2010, 2, 14-34. [CrossRef]

54. Datu, J.A.D. Flourishing is Associated with Higher Academic Achievement and Engagement in Filipino Undergraduate and High School Students. J. Happiness Stud. 2018, 19, 27-39. [CrossRef]

55. Lewis, A.D.; Huebner, E.S.; Reschly, A.L.; Valois, R.F. The Incremental Validity of Positive Emotions in Predicting School Functioning. J. Psychoeduc. Assess. 2009, 27, 397-408. [CrossRef]

56. Isen, A.M.; Reeve, J. The Influence of Positive Affect on Intrinsic and Extrinsic Motivation: Facilitating Enjoyment of Play, Responsible Work Behavior, and Self-Control. Motiv. Emot. 2005, 29, 295-323. [CrossRef]

57. Coffey, J.K.; Wray-Lake, L.; Mashek, D.; Branand, B. A Multi-Study Examination of Well-Being Theory in College and Community Samples. J. Happiness Stud. 2016, 17, 187-211. [CrossRef]

58. Howell, A.J.; Buro, K. Measuring and Predicting Student Well-Being: Further Evidence in Support of the Flourishing Scale and the Scale of Positive and Negative Experiences. Soc. Indic. Res. 2015, 121, 903-915. [CrossRef]

59. Green, J.; Nelson, G.; Martin, A.; Marsh, H. The causal ordering of self-concept and academic motivation and its effect on academic achievement. Int. Educ. J. 2006, 7, 534-546.

60. Maltby, J.; Day, L.; McCutcheon, L.E.; Gillett, R.; Houran, J.; Ashe, D.D. Personality and coping: A context for examining celebrity worship and mental health. Br. J. Psychol. 2004, 95, 411-428. [CrossRef]

61. Keyes, C.L.M.; Eisenberg, D.; Perry, G.S.; Dube, S.R.; Kroenke, K.; Dhingra, S.S. The Relationship of Level of Positive Mental Health With Current Mental Disorders in Predicting Suicidal Behavior and Academic Impairment in College Students. J. Am. Coll. Health 2012, 60, 126-133. [CrossRef]

62. Gilman, R.; Huebner, E.S. Characteristics of Adolescents Who Report Very High Life Satisfaction. J. Youth Adolesc. 2006, 35, 293-301. [CrossRef]

63. Heffner, A.L.; Antaramian, S.P. The Role of Life Satisfaction in Predicting Student Engagement and Achievement. J. Happiness Stud. 2016, 17, 1681-1701. [CrossRef]

64. Huebner, E.S.; Hills, K.J.; Siddall, J.; Gilman, R. Life satisfaction and schooling. In Handbook of Positive Psychology in Schools, 2nd ed.; Educational Psychology Handbook Series; Routledge/Taylor \& Francis Group: New York, NY, USA, 2014; pp. 192-207. ISBN 978-0-415-62185-4.

65. Long, R.F.; Huebner, E.S. Differential Validity of Global and Domain-Specific Measures of Life Satisfaction in the Context of Schooling. Child Indic. Res. 2014, 7, 671-694. [CrossRef]

66. Brighouse, H. On Education; Routledge: London, UK; New York, NY, USA, 2006; ISBN 041532789X.

67. Curwen, B.; Palmer, S.; Ruddell, P. Brief Cognitive Behaviour Therapy; SAGE Publications Ltd.: London, UK, 2000; ISBN 9780761958017.

68. Evans, J.S.B.T.; Stanovich, K.E. Dual-Process Theories of Higher Cognition. Perspect. Psychol. Sci. 2013, 8, 223-241. [CrossRef] [PubMed]

69. Wong, S.S. Balanced states of mind in psychopathology and psychological well-being. Int. J. Psychol. 2010, 45, 269-277. [CrossRef] [PubMed]

70. Gray, G. A Review of Psychometric Data Analysis and Applications in Modelling of Academic Achievement in Tertiary Education. J. Learn. Anal. 2014, 1, 75-106. [CrossRef]

71. Chamorro-Premuzic, T.; Furnham, A. A possible model for understanding the personality-intelligence interface. Br. J. Psychol. 2004, 95, 249-264. [CrossRef] 
72. Chamorro-Premuzic, T.; Furnham, A. Personality, intelligence and approaches to learning as predictors of academic performance. Personal. Individ. Differ. 2008, 44, 1596-1603. [CrossRef]

73. De Feyter, T.; Caers, R.; Vigna, C.; Berings, D. Unraveling the impact of the Big Five personality traits on academic performance: The moderating and mediating effects of self-efficacy and academic motivation. Learn. Individ. Differ. 2012, 22, 439-448. [CrossRef]

74. Law, K.M.Y.; Lee, V.C.S.; Yu, Y.T. Learning motivation in e-learning facilitated computer programming courses. Comput. Educ. 2010, 55, 218-228. [CrossRef]

75. Hawi, N. Causal attributions of success and failure made by undergraduate students in an introductory-level computer programming course. Comput. Educ. 2010, 54, 1127-1136. [CrossRef]

76. Blut, M.; Wang, C. Technology readiness: A meta-analysis of conceptualizations of the construct and its impact on technology usage. J. Acad. Mark. Sci. 2020, 48, 649-669. [CrossRef]

77. Scherer, R.; Siddiq, F.; Sánchez Viveros, B. The cognitive benefits of learning computer programming: A meta-analysis of transfer effects. J. Educ. Psychol. 2019, 111, 764-792. [CrossRef]

78. Dirzyte, A.; Vijaikis, A.; Perminas, A.; Rimasiute-Knabikiene, R.; Kaminskis, L.; Zebrauskas, G. Computer Programming E-Learners' Personality Traits, Self-Reported Cognitive Abilities, and Learning Motivating Factors. Brain Sci. 2021, 11, 1205. [CrossRef]

79. LaBelle, S.; Johnson, Z.D. The relationship of student-to-student confirmation in the classroom to college students' mental health and well-being. Commun. Q. 2021, 69, 133-151. [CrossRef]

80. Tang, Y.M.; Chen, P.C.; Law, K.M.Y.; Wu, C.H.; Lau, Y.; Guan, J.; He, D.; Ho, G.T.S. Comparative analysis of Student's live online learning readiness during the coronavirus (COVID-19) pandemic in the higher education sector. Comput. Educ. 2021, $168,104211$. [CrossRef]

81. Sumi, K. Reliability and Validity of Japanese Versions of the Flourishing Scale and the Scale of Positive and Negative Experience. Soc. Indic. Res. 2014, 118, 601-615. [CrossRef]

82. De la Fuente, R.; Parra, A.; Sánchez-Queija, I. Psychometric Properties of the Flourishing Scale and Measurement Invariance Between Two Samples of Spanish University Students. Eval. Health Prof. 2017, 40, 409-424. [CrossRef] [PubMed]

83. Giuntoli, L.; Ceccarini, F.; Sica, C.; Caudek, C. Validation of the Italian Versions of the Flourishing Scale and of the Scale of Positive and Negative Experience. SAGE Open 2017, 7, 215824401668229. [CrossRef]

84. Didino, D.; Taran, E.A.; Barysheva, G.A.; Casati, F. Psychometric evaluation of the Russian version of the flourishing scale in a sample of older adults living in Siberia. Health Qual. Life Outcomes 2019, 17, 34. [CrossRef] [PubMed]

85. Fornell, C.; Larcker, D.F. Evaluating Structural Equation Models with Unobservable Variables and Measurement Error. J. Mark. Res. 1981, 18, 39-50. [CrossRef]

86. Al-Adwan, A.S.; Albelbisi, N.A.; Hujran, O.; Al-Rahmi, W.M.; Alkhalifah, A. Developing a Holistic Success Model for Sustainable E-Learning: A Structural Equation Modeling Approach. Sustainability 2021, 13, 9453. [CrossRef]

87. Chin, W.; Cheah, J.-H.; Liu, Y.; Ting, H.; Lim, X.-J.; Cham, T.H. Demystifying the role of causal-predictive modeling using partial least squares structural equation modeling in information systems research. Ind. Manag. Data Syst. 2020, 120, 2161-2209. [CrossRef]

88. Sarstedt, M.; Hair, J.F.; Cheah, J.-H.; Becker, J.-M.; Ringle, C.M. How to Specify, Estimate, and Validate Higher-Order Constructs in PLS-SEM. Australas. Mark. J. 2019, 27, 197-211. [CrossRef]

89. Sitar-Taut, D.-A.; Mican, D. Mobile learning acceptance and use in higher education during social distancing circumstances: An expansion and customization of UTAUT2. Online Inf. Rev. 2021, 45, 1000-1019. [CrossRef]

90. Sitar-Tăut, D. Mobile learning acceptance in social distancing during the COVID-19 outbreak: The mediation effect of hedonic motivation. Hum. Behav. Emerg. Technol. 2021, 3, 366-378. [CrossRef]

91. Dutta, B.; Peng, M.-H.; Chen, C.-C.; Sun, S.-L. Interpreting Usability Factors Predicting Sustainable Adoption of Cloud-Based E-Learning Environment during COVID-19 Pandemic. Sustainability 2021, 13, 9329. [CrossRef]

92. Hair, J.; Hollingsworth, C.L.; Randolph, A.B.; Chong, A.Y.L. An updated and expanded assessment of PLS-SEM in information systems research. Ind. Manag. Data Syst. 2017, 117, 442-458. [CrossRef]

93. Hoi, V.N. Understanding higher education learners' acceptance and use of mobile devices for language learning: A Rasch-based path modeling approach. Comput. Educ. 2020, 146, 103761. [CrossRef]

94. Hair, J.F.; Hult, G.T.M.; Ringle, C.M.; Sarstedt, M. A Primer on Partial Least Squares Structural Equation Modeling (PLS-SEM), 2nd ed.; SAGE Publications: Thousand Oaks, CA, USA, 2017; ISBN 9781483377445.

95. Mastromartino, B.; Wang, J.J.; Suggs, D.W.; Hollenbeck, C.R.; Zhang, J.J. Dimensions of Sense of Membership in a Sport Fan Community: Factors, Outcomes, and Social Capital Implications. Commun. Sport 2020, 216747952095637. [CrossRef]

96. Mican, D.; Sitar-Tăut, D.-A.; Moisescu, O.-I. Perceived usefulness: A silver bullet to assure user data availability for online recommendation systems. Decis. Support Syst. 2020, 139, 113420. [CrossRef]

97. Mican, D.; Sitar-Tăut, D.-A.; Mihuț, I.-S. User Behavior on Online Social Networks: Relationships among Social Activities and Satisfaction. Symmetry 2020, 12, 1656. [CrossRef]

98. Raza, S.A.; Qazi, W.; Khan, K.A.; Salam, J. Social Isolation and Acceptance of the Learning Management System (LMS) in the time of COVID-19 Pandemic: An Expansion of the UTAUT Model. J. Educ. Comput. Res. 2021, 59, 183-208. [CrossRef]

99. Kline, R.B. Principles and Practice of Structural Equation Modeling, 4th ed.; Methodology in the Social Sciences; Guilford Press: New York, NY, USA, 2016; ISBN 978-1-4625-2334-4. 
100. Bryne, B. Structural Equation Modeling with AMOS: Basic Concepts, Applications, and Programming. J. Appl. Quant. Methods 2010, 5, 365-368.

101. Murtaugh, P.A. In defense of P values. Ecology 2014, 95, 611-617. [CrossRef]

102. Kercher, A.J.; Rapee, R.M.; Schniering, C.A. Neuroticism, Life Events and Negative Thoughts in the Development of Depression in Adolescent Girls. J. Abnorm. Child Psychol. 2009, 37, 903-915. [CrossRef]

103. Schotanus-Dijkstra, M.; Pieterse, M.E.; Drossaert, C.H.C.; Westerhof, G.J.; de Graaf, R.; ten Have, M.; Walburg, J.A.; Bohlmeijer, E.T. What Factors are Associated with Flourishing? Results from a Large Representative National Sample. J. Happiness Stud. 2016, 17, 1351-1370. [CrossRef]

104. Di Fabio, A.; Gori, A. Neuroticism and flourishing in white collar workers: From self-esteem to intrapreneurial self-capital for adaptive outcomes. In Neuroticism: Characteristics, Impact on Job Performance and Health Outcomes; Psychology of Emotions, Motivations and Actions; Nova Science Publishers: New York, NY, USA, 2016; pp. 129-146, ISBN 978-1-63485-323-1.

105. Zhang, D.C.; Renshaw, T.L. Personality and College Student Subjective Wellbeing: A Domain-Specific Approach. J. Happiness Stud. 2020, 21, 997-1014. [CrossRef]

106. Lee, M.T.; Bialowolski, P.; Weziak-Bialowolska, D.; Mooney, K.D.; Lerner, P.J.; McNeely, E.; VanderWeele, T.J. Self-assessed importance of domains of flourishing: Demographics and correlations with well-being. J. Posit. Psychol. 2021, 16, 137-144. [CrossRef]

107. Grieve, R.; Kemp, N. Individual differences predicting social connectedness derived from Facebook: Some unexpected findings. Comput. Hum. Behav. 2015, 51, 239-243. [CrossRef]

108. Weziak-Bialowolska, D.; Bialowolski, P.; Lee, M.T.; Chen, Y.; VanderWeele, T.J.; McNeely, E. Psychometric Properties of Flourishing Scales From a Comprehensive Well-Being Assessment. Front. Psychol. 2021, 12, 652209. [CrossRef]

109. Widnall, E.; Price, A.; Trompetter, H.; Dunn, B.D. Routine Cognitive Behavioural Therapy for Anxiety and Depression is More Effective at Repairing Symptoms of Psychopathology than Enhancing Wellbeing. Cogn. Ther. Res. 2020, 44, 28-39. [CrossRef]

110. Wong, S.S. Negative thinking versus positive thinking in a Singaporean student sample: Relationships with psychological well-being and psychological maladjustment. Learn. Individ. Differ. 2012, 22, 76-82. [CrossRef]

111. McNulty, J.K.; Fincham, F.D. Beyond positive psychology? Toward a contextual view of psychological processes and well-being. Am. Psychol. 2012, 67, 101-110. [CrossRef]

112. Frisby, B.N.; Martin, M.M. Instructor-Student and Student-Student Rapport in the Classroom. Commun. Educ. 2010, 59, 146-164. [CrossRef]

113. Reis, H.T.; Lemay, E.P.; Finkenauer, C. Toward understanding understanding: The importance of feeling understood in relationships. Soc. Personal. Psychol. Compass 2017, 11, e12308. [CrossRef]

114. Xu, J.; Yang, H.H.; MacLeod, J. STEP on connected classroom climate in a hybrid learning environment. Int. J. Innov. Learn. 2018, 23, 430. [CrossRef]

115. MacLeod, J.; Yang, H.H.; Shi, Y. Student-to-student connectedness in higher education: A systematic literature review. J. Comput. High. Educ. 2019, 31, 426-448. [CrossRef]

116. Di Fabio, A. The psychology of sustainability and sustainable development for well-being in organizations. Front. Psychol. 2017, 8, 1534. [CrossRef]

117. Borovay, L.A.; Shore, B.M.; Caccese, C.; Yang, E.; Hua, O. (Liv) Flow, Achievement Level, and Inquiry-Based Learning. J. Adv. Acad. 2019, 30, 74-106. [CrossRef]

118. Hong, J.-C.; Liu, Y.; Liu, Y.; Zhao, L. High School Students' Online Learning Ineffectiveness in Experimental Courses During the COVID-19 Pandemic. Front. Psychol. 2021, 12, 738695. [CrossRef]

119. Di Fabio, A.; Rosen, M.A. Opening the Black Box of Psychological Processes in the Science of Sustainable Development: A New Frontier. Eur. J. Sustain. Dev. Res. 2018, 2, 47. [CrossRef] 